\title{
Two global data sets of daily fire emission injection heights since 2003
}

\author{
Samuel Rémy ${ }^{1}$, Andreas Veira ${ }^{2}$, Ronan Paugam ${ }^{3}$, Mikhail Sofiev $^{4}$, Johannes W. Kaiser $^{5}$, Franco Marenco ${ }^{6}$, \\ Sharon P. Burton ${ }^{7}$, Angela Benedetti ${ }^{8}$, Richard J. Engelen ${ }^{8}$, Richard Ferrare ${ }^{7}$, and Jonathan W. Hair ${ }^{7}$ \\ ${ }^{1}$ Laboratoire de Météorologie Dynamique, UPMC/CNRS, Paris, France \\ ${ }^{2}$ Max Planck Institute for Meteorology, Hamburg, Germany \\ ${ }^{3}$ King's College, London, UK \\ ${ }^{4}$ Finnish Meteorological Institute, Helsinki, Finland \\ ${ }^{5}$ Max Planck Institute for Chemistry, Mainz, Germany \\ ${ }^{6}$ Satellite Applications, Met Office, Exeter, UK \\ ${ }^{7}$ National Aeronautics and Space Administration, Langley Research Center, Hampton, CA, USA \\ ${ }^{8}$ European Centre for Medium-range Weather Forecasts, Reading, UK \\ Correspondence to: Samuel Rémy (samuel.remy@ecmwf.int, samuel.remy@1md.jussieu.fr)
}

Received: 22 December 2015 - Discussion started: 13 April 2016

Revised: 18 October 2016 - Accepted: 22 December 2016 - Published: 27 February 2017

\begin{abstract}
The Global Fire Assimilation System (GFAS) assimilates fire radiative power (FRP) observations from satellite-based sensors to produce daily estimates of biomass burning emissions. It has been extended to include information about injection heights derived from fire observations and meteorological information from the operational weather forecasts of ECMWF.

Injection heights are provided by two distinct methods: the Integrated Monitoring and Modelling System for wildland fires (IS4FIRES) parameterisation and the one-dimensional plume rise model (PRM). A global database of daily biomass burning emissions and injection heights at $0.1^{\circ}$ resolution has been produced for 2003-2015 and is continuously extended in near-real time with the operational GFAS service of the Copernicus Atmospheric Monitoring Service (CAMS).

In this study, the two injection height data sets were compared with the new MPHP2 (MISR Plume Height Project 2) satellite-based plume height retrievals. The IS4FIRES parameterisation showed a better overall agreement than the observations, while the PRM was better at capturing the variability of injection heights. The performance of both parameterisations is also dependent on the type of vegetation.

Furthermore, the use of biomass burning emission heights from GFAS in atmospheric composition forecasts was assessed in two case studies: the South AMerican Biomass
\end{abstract}

Burning Analysis (SAMBBA) campaign which took place in September 2012 in Brazil, and a series of large fire events in the western USA in August 2013. For these case studies, forecasts of biomass burning aerosol species by the Composition Integrated Forecasting System (C-IFS) of CAMS were found to better reproduce the observed vertical distribution when using PRM injection heights from GFAS compared to aerosols emissions being prescribed at the surface.

The globally available GFAS injection heights introduced and evaluated in this study provide a comprehensive data set for future fire and atmospheric composition modelling studies.

\section{Introduction}

Vegetation fires are responsible for the release of large quantities of trace gases and aerosols into the atmosphere (Andreae and Merlet, 2001; Van der Werf et al., 2010). Each year, around 3 million $\mathrm{km}^{2}$ of land are burnt worldwide (Giglio et al., 2010) by landscape fires ignited by natural or anthropogenic causes. A wide range of atmospheric processes are affected by fire emissions, including radiative transfer, turbulent diffusion, cloud microphysics and atmospheric chemistry (Twomey, 1977; Heald et al., 2014; Veira et al., 2015b 
among others). Fires cause large emissions of particulate matter; they have been estimated at $2-11 \mathrm{Tg}$ of black carbon per year and $18-77 \mathrm{Tg}$ of organic carbon per year (Bond et al., 2013, and references therein). This can result in acute air quality problems, such as in Singapore in June 2013, for example, when the air quality index reached record values because of smoke from fires in nearby Sumatra.

Several global fire emission databases have been developed in recent years: FLAMBE (Fire Locating and Modeling of Burning Emissions), GFED (Global Fire Emissions Database), FINN (Fire INventory from NCAR), QFED (Quick Fire Emission Dataset), IS4FIRES and GFAS (Reid et al., 2009; Van der Werf et al., 2010 and Giglio et al., 2013; Wiedinmyer et al., 2011; Darmenov and da Silva, 2013; Sofiev et al., 2009; Kaiser et al., 2012, respectively). All of these products rely on satellite observations of fire radiative power (FRP), hot spots or burnt areas because they alone provide sufficient spatial coverage and temporal sampling frequency (Giglio et al., 2006; Kaiser et al., 2012).

When a fire is in the flaming combustion stage, the intense heat from the burning vegetation creates a rising plume which interacts with the ambient atmosphere and transports the fire emissions vertically (Freitas et al., 2006; Paugam et al., 2016). Because of this fire-induced convection, biomass burning is one of the few processes that emits large quantities of aerosols and trace gases well above the planetary boundary layer $(\mathrm{PBL})$, sometimes even reaching the upper troposphere/lower stratosphere (Andreae et al., 2004; Fromm et al., 2005; Dahlkötter et al., 2013). Using observations from the Multi-angle Imaging SpectroRadiometer (MISR) instrument on board Terra, Kahn et al. (2008) estimated that 5 to $18 \%$ of fires that occurred over Alaska and Canadian Yukon in 2004 released smoke constituents above the PBL. A 5-year record of MISR observations by Val Martin et al. (2010) found a similar figure. Sofiev et al. (2012), using an injection height parameterisation, found that $15 \%$ of fire plumes reached the free troposphere. Fires in the smoldering stage can also produce a significant amount of smoke, which is mostly released just above the surface, e.g. Tosca et al. (2011).

Fire emission height, i.e. the height at which the fire releases emissions into the atmosphere, has been identified as a crucial parameter to influence the forecasts of the life cycle of biomass burning aerosols. In particular, whether smoke constituents are released below or above the top of the PBL will have profound consequences on their transport, deposition and life cycle. There are significant uncertainties in the vertical distribution of aerosols in global models (Textor et al., 2006), which has an impact on estimating the magnitude of the direct radiative forcing of aerosols (Choi and Chung, 2014).

The height at which smoke constituents are released depends on the atmospheric environment and on the intensity of the updraught generated by the fire, which itself depends on a variety of parameters (Kahn et al., 2007); foremost among them are the sensible heat flux and the size of the fire. The ambient atmosphere has a 2-fold impact on the vertical transport in a fire plume: the thermal stratification acts more or less strongly against the buoyancy triggered by the sensible heat released by the fire. Because the environment is cooler than the plume, water vapour condensation and latent heat release occur, with the formation of pyrocumulus and/or pyrocumulonimbus (Fromm et al., 2010); this can accelerate the vertical transport in the smoke plume. The vertical windshear also has an impact on both the vertical and the horizontal developments of the plume.

Several theories and models describing the dynamics of plume rise have been developed. The algorithms available today are summed up in Paugam et al. (2016) and Veira et al. (2015a). They can be divided into two families: semiempirical models (Achtemeier et al., 2011, and Sofiev et al., 2012, for example) and numerical one-dimensional plume rise models (PRMs) such as the one developed by Latham (1994) and further refined by Freitas et al. (2007) and others. All of these models use atmospheric profiles of meteorological parameters as input, together with satellite information on fire size and/or activity. Their output is either an injection height or a full smoke detrainment profile.

The Global Fire Assimilation System (GFAS) of the EUfunded operational Copernicus Atmosphere Monitoring Service (CAMS; Hollingsworth et al., 2008; Flemming et al., 2015) has recently been updated to include injection height information based on the IS4FIRES parameterisation (Sofiev et al., 2012) and a PRM (Freitas et al., 2007). These new products have been calculated for the time period since 2003 and are being continued as an operational near-real-time service on a daily basis. They are freely available online at http://apps.ecmwf.int/datasets/data/cams-gfas.

In this study, we describe the GFAS update in detail, validate the new injection height information against MISR observations and demonstrate its positive impact on atmospheric aerosol simulations in two case studies. In Sect. 2, we present the IS4FIRES and PRM algorithms as well as the verification data set from MPHP2. The C-IFS model is also introduced in this section. Section 3 details how the injection heights algorithms were embedded in GFAS. Section 4 shows the two injection height data sets and their validation against the MPHP2 data set. Section 5 presents two applications of injection heights from GFAS using the C-IFS atmospheric composition model for two field campaigns in South America and the USA. The paper then summarises our conclusions and provides details on the recent updates of the PRM in Appendix A.

\section{Methodology: models and data}

A model that aims to predict the evolution of a smoke plume with time typically uses two kind of inputs: information about the environment (temperature and wind profiles), and 


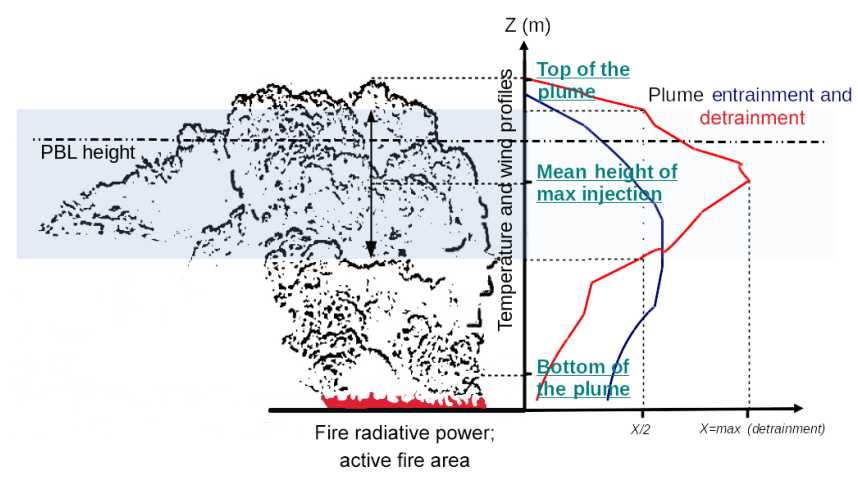

Figure 1. Schematic of an algorithm estimating plume injection height parameters. The fire input (fire radiative power and fire area) and the environmental input (temperature and wind profiles) are shown, as well as the possible output of the model: detrainment and entrainment profiles, with the derived quantities (bottom of the plume, top of the plume, mean height of maximum injection), or injection height, usually defined as the top of the plume.

about the fire (Fire Radiative Power and fire area). Figure 1 shows a schematic sketch of how a fire plume is modelled using these inputs and the various injection height parameters that are used in this study. Plume detrainment is the quantity of smoke that is shed by the plume into the environment. The various injection height parameters are shown: mean height of maximum injection, bottom of the plume and top of the plume. Detrainment is used to define the mean height of maximum injection, which corresponds to the average of the plume heights at which detrainment exceeds half of the maximum value.

\subsection{Plume rise model (PRM)}

The PRM comes in two versions: v0, used in the work of Val Martin et al. (2012) and Strada et al. (2013) and described in detail in Freitas et al. $(2007,2010)$, and v2 which is presented in Paugam et al. (2015). The modifications brought by Paugam et al. (2015) concern mass conservation and the entrainment scheme; they are summarised in Appendix A. In this work, PRM v2 is used and the term "PRM" will denote this particular version. The plume rise model consists of a 1-D cloud-resolving model, forced at its base by satellitederived fire parameters: convective heat flux (CHF) and active fire area (AF area). To account for possible condensation and formation of pyrocumulus, the PRM also includes a bulk microphysical scheme based on Kessler (1969). Four prognostic variables: vertical velocity; temperature; horizontal plume velocity and the radius of the plume are forecasted by the model. These four variables are governed by equations based on the vertical motion and mass conservation equations as well as the first thermodynamic law (Freitas et al., 2007).

The PRM is run using a $100 \mathrm{~m}$ resolution vertical grid, reaching a maximum height of $20 \mathrm{~km}$. The time step is adap- tive, computed to respect the Courant-Friedrich-Levy numerical stability criterion, with an upper limit of $5 \mathrm{~s}$ (Freitas et al., 2007). The ambient atmospheric profiles of temperature, wind and specific humidity are taken from $3 \mathrm{~h}$ European Centre for Medium-Range Forecasts (ECMWF) data.

Besides the atmospheric profiles, the main inputs of the PRM are CHF and AF area. CHF is defined as follows:

$\mathrm{CHF}=\beta \cdot \mathrm{FRP}$,

where $\beta$ is a scaling factor (see Appendix A for the values of the parameters of the PRMv2). The active fire area is estimated from MODIS observations in the midand thermal-infrared channels using the Dozier algorithm, (Dozier, 1981)) on clusters of contiguous active fire pixels. Injection heights are computed only for fires with an area above 1 ha, and a MODIS subpixel effective temperature above $600 \mathrm{~K}$, to prevent taking into account smoldering fires. There is no output for these fires of which most the emissions take place close to the surface.

\subsection{IS4FIRES}

The semi-empirical IS4FIRES parameterisation is detailed in Sofiev et al. (2012). Injection height is estimated as a function of the PBL height, the Brunt-Väisälä frequency of the free troposphere and the FRP of a fire. In our implementation, the PBL height is provided by the operational ECMWF model, which uses the Troen and Mahrt (1986) diagnostic: PBL height is defined as the level at which the bulk Richardson number, based on the difference between quantities at that level and the lowest model level, reaches the critical value 0.25 . An evaluation of this product against satellite retrievals (Palm et al., 2005) showed that the diagnostic often underestimates the PBL height by a few hundred metres but shows a good correlation with observations. In this work the two-step version of the IS4FIRES algorithm is used.

IS4FIRES was further refined by Kukkonen et al. (2014) and Veira et al. (2015a). Kukkonen et al. (2014) improved the results of the algorithm when replacing the Brunt-Väisälä frequency of the free troposphere with the inversion layer Brunt-Väisälä frequency in case of a stable nocturnal boundary layer. Since our proposed implementation will use a daily FRP product that is based on daytime satellite observations from MODIS, this improvement was not tested and its impact would probably not be significant.

\subsection{MISR plume heights: MPHP2}

The MPHP plume height data set is a combination of the MISR smoke aerosol and the MODIS MOD14 thermal anomaly products. The MISR instrument is hosted by Terra and consists of nine cameras that view the Earth at different angles, in four spectral channels in the visible and nearinfrared spectrum. The height of the smoke plume is retrieved stereoscopically by measuring the parallax observed between 
pairs of camera images out of a total of nine cameras (Nelson et al., 2013). A correction is applied to account for the movement of the plume using an externally provided wind direction. The latest release of the MPHP (April 2012) includes data of wildfire smoke plumes in North and South America, Eurasia, Africa and South-east Asia, observed between 2001 and 2009. For more detailed information, see the official product description at http://www-misr.jpl.nasa. gov/getData/accessData/MisrMinxPlumes/. As stated in the MPHP data quality statement, important biases are introduced by pyrocumulus clouds which hide below-cloud fire activity (Kahn et al., 2008), by errors in the digitisation of the plumes and large uncertainties in the MODIS fire pixels.

The MPHP2 data set that was released in July 2015 uses a new version of the satellite retrieval software, with the addition of a blue-band height retrieval to the existing red-band retrieval, which should enhance the quality of the data set for optically thin plumes over bright surfaces. The MISR conventional red-band retrieval of height for optically thin smoke over relatively bright terrain is frequently unsuccessful and may under-estimate smoke height. Height retrievals for many plumes in the MPHP2 data set used the blue-band retrieval, resulting in a significant increase in the number of successful plume retrievals. The MPHP2 data set includes over 32000 fire plumes for the year 2008. When excluding plumes of poor retrieval quality, the MPHP2 data set provides 13454 injection heights which we will use to validate the injection heights from the two algorithms embedded into GFAS.

According to the official MPHP product description as well as Kahn et al. (2008) and Nelson et al. (2013), an observational plume height accuracy of about $200 \mathrm{~m}$ can be assumed in good conditions. In the absence of a different prescription for the new data set, we will use the same value for the MPHP2 data set.

\subsection{The C-IFS forecasting system}

The C-IFS global atmospheric composition model is an assimilation and forecasting system for monitoring aerosols, greenhouse gases and reactive gases, using satellite observations and a combination of global and regional models (Hollingsworth et al., 2008; Peuch and Engelen, 2012) operated by CAMS. The meteorological component of C-IFS is based on the ECWMF operational model, the Integrated Forecast System (IFS). The trace gases component of C-IFS is described in Flemming et al. (2015).

Aerosols are forecasted within the C-IFS global system by a forward model (Morcrette et al., 2009, based on earlier work by Reddy et al., 2005 and Boucher et al., 2002) that uses five species: dust, sea-salt, black carbon, organic matter and sulfates. GFAS provides the biomass burning emissions of black carbon, organic matter and sulfates. In this chapter the sum of black carbon (BC) and organic matter (OM) is hereafter denoted "biomass burning aerosols". Sulfates were excluded because for there are many other important sources for this species besides fires. C-IFS provides and uses aerosol analysis by assimilating total aerosol optical depth (AOD) observations from MODIS in a 4D-Var assimilation algorithm, as described in Benedetti et al. (2009).

The prognostic variables of C-IFS are mass mixing ratios. Extinction and AOD at 17 wavelengths (see Table 1 of Morcrette et al., 2009) are diagnosed using a standard Mie-scattering algorithm (Ackerman and Toon, 1981) using an external mixing assumption. Absorption and scattering coefficients for organic and black carbon, and sulfate were adapted from those in the LOA/LMD-Z model. For more information, please refer to Table 2 and Fig. 1 of Reddy et al. (2005).

\section{Integration of IS4FIRES and PRM in GFAS}

\subsection{Overview of the Global Fire Assimilation System (GFAS)}

CAMS provides global analysis and forecasts of atmospheric composition, alongside European air quality forecasts (Hollingsworth et al., 2008) using the C-IFS model (Morcrette et al., 2009; Benedetti et al., 2009; Peuch and Engelen, 2012; Flemming et al., 2015). In order to provide this forecasting system with accurate estimates of aerosol, reactive gases and greenhouse gas emissions from biomass burning, GFAS (Kaiser et al., 2009, 2012) uses satellite measurements of fire radiative power (FRP) to estimate fire emissions. GFAS is operated operationally within the CAMS project and provides daily estimates of FRP, burnt dry matter and biomass burning emissions of 41 species.

GFAS grids and averages FRP observations from the MODIS instrument on board the National Aeronautics and Space Administration (NASA) Terra and Aqua satellites. The gridded data from the two satellites are then merged to produce global daily averaged FRP fields with $0.1^{\circ}$ resolution. Analyses of daily averaged FRP are constructed by assimilating these merged daily averaged FRP observations. The assimilation step consists of a simple Kalman filter used with a persistence model. The objective of the data assimilation step is to correct for gaps in the observations, caused mainly by cloudy conditions (sometimes caused by pyrocumulus or pyrocumulonimbus). Spurious FRP observations of volcanoes, gas flares and other industrial activity are masked using a fixed spurious signal mask.

Correlations between FRP and fuel consumption with fire emission were found in several contexts: Wooster et al. (2005) demonstrated this for fuel consumption in laboratory studies, Ichoku and Kaufman (2005) documented it for aerosol emission observed by satellite, and Heil et al. (2010) found strong, but biome-specific, correlations between FRP and the dry-matter combustion rate of GFEDv3.1 (Van der Werf et al., 2010). This allowed the derivation of conver- 
sion factors for eight land cover classes that link GFAS FRP to the GFED dry-matter combustion rate, and subsequently the estimation of global dry-matter burnt fields with GFAS. Emission factors following Andreae and Merlet (2001) and updates are then used to estimate the emissions of 41 species from the burnt dry matter.

The GFAS emission inventory covers the period from 1 January 2003 to the present. It has been recently extended to early 2000 (Remy and Kaiser, 2014) using bias-corrected observations from MODIS on board Terra only. The output from GFAS is regularly validated in the framework of the CAMS project (e.g. Andela et al., 2013).

\subsection{Integration of the injection height algorithms into GFAS}

The output of the IS4FIRES parameterisation is a single parameter, injection height, which makes it easy to assimilate once gridded and averaged. The output of the PRM is a whole detrainment profile, which would be too costly to assimilate. It was decided instead to derive the most useful parameters from this profile and then to regrid and assimilate them. These parameters consist of the top and the bottom of the plume, and of the mean height of maximum injection, i.e. the average of the PRM levels to which detrainment is equal or above half of the maximum detrainment.

The clustering algorithm of the PRM was used to produce clusters of contiguous MODIS fire pixels. The PRM was run with accumulated FRP of each fire cluster as an input while the maximum FRP of each cluster was used as input to IS4FIRES, so as to use inputs that are similar to Sofiev et al. (2012).

The output of the PRM is very dependent on the stability of the atmosphere. One possible drawback is that in some cases, the impact of the fire forcing at the base of the 1-D column of the PRM becomes negligible compared to the impact of the atmospheric environment. In that case, the injection profiles produced by the PRM are only representative of the convective updraughts in the environment, but not for the pyrogenic convection. To prevent this, the PRM is run twice, once with no fire forcing and another time with the fire forcing. Only the fire clusters for which the mean height of maximum injection provided by the PRM forced by the fire is larger than the one provided by the PRM not forced by the fire are kept. This particular criterion removes around $10 \%$ of active fire clusters.

The two injection height algorithms provide four parameters for each $5 \mathrm{mn}$ MODIS granule: three for the PRM (mean height of maximum injection, height of the top of the plume and of the bottom of plume), and one for IS4FIRES. These parameters must first be gridded onto the $0.1 \times 0.1^{\circ}$ GFAS grid. To achieve that, the number and coordinates of all the MODIS pixels that constitute the fire clusters are kept. Each GFAS grid cell containing at least one pixel of a given fire cluster is then associated with the values of the four injec- tion heights of this fire cluster. In the case in which a GFAS grid cell contains pixels from two or more distinct fire clusters, the maximum value of the fire clusters is assigned to the GFAS grid cell. Maximum FRP from each fire cluster is also gridded in the same way.

In GFAS, the time averaging of the $5 \mathrm{mn}$ global gridded FRP into hourly and daily global gridded FRP uses the fraction of satellite-observed area as a weight. For the injection height parameters it was decided to use the gridded maximum FRP as a weight in order to privilege injection heights associated with the most active fires. This means that the resulting product is more representative of the diurnal maximum of fire intensity. The rationale behind this choice is that several studies showed that most emissions from biomass burning occur within a few hours of a peak time, typically during the early afternoon (Andela et al., 2015; Freeborn et al., 2009, 2011; Roberts et al., 2009). The daily gridded fields of the four injection height parameters are then assimilated alongside FRP in the data assimilation step of GFAS.

There are many GFAS grid cells with non-null FRP and biomass burning emissions with null injection heights because the PRM does not always produce a detrainment profile for a given fire cluster (depending on fire temperature, fire size and the output from the non-forced PRM mentioned above). In most cases, these grid cells correspond to fires in the smoldering stage for which most of the plume material is emitted close to the surface. For these grid cells, it is recommended for atmospheric composition applications to release biomass burning emissions at the surface. In all, only 33 to $35 \%$ of GFAS grid cells with positive fire emissions also have positive injection height parameters. They correspond to fires in the flaming stage.

\section{Results and validation}

In this section, the outputs of the two algorithms embedded in GFAS are evaluated: injection height for IS4FIRES and mean height of maximum injection for the PRM (see Fig. 1 for a sketch), i.e. the average of the PRM levels for which detrainment is above half of the maximum detrainment. The injection height from IS4FIRES corresponds to the top of the plume, as do the MPHP2 retrievals. However, the mean height of maximum injection was chosen as the reference output from the PRM because the plume top often appeared to be much higher than the height of maximum injection, which is not often the case for real fires. For the sake of simplicity, the mean height of maximum injection from the PRM will also be called "injection height".

\subsection{Comparison of the raw output of the two algorithms}

Figure 3 shows density plots of the injection height provided by the IS4FIRES parameterisation against the boundary layer 


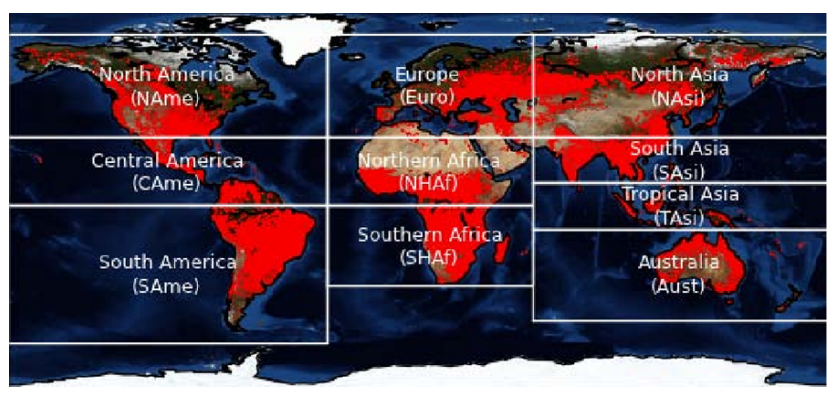

Figure 2. Regions of interest as defined in Kaiser et al. (2012).

height diagnostic from the operational ECMWF model, for global Terra and Aqua observations and for the 1 June to 1 August 2013 period. The injection heights are neatly separated into two distinct subsets: one below the PBL height, with a large variability, and another just above PBL height with low variability. The two subsets are clearly a result of the two steps of the algorithm, with the second step being applied only to plumes that are rising higher than the PBL height. However, it is apparent from this plot that IS4FIRES encounters difficulties when providing injection heights that are significantly above PBL height.

The same plot also shows density plots of the mean height of maximum injection provided by the PRM against the boundary layer height diagnostic from the operational ECMWF model, for global Terra and Aqua observations and for the 1 June to 1 August 2013 period. The impact of the thermal stratification of the atmosphere is apparent: for most of the fire plumes, maximum detrainment occurs just under the top of the PBL, where a temperature inversion sometimes occurs and may block the vertical development of fire plumes. Maximum injection occurs higher with Aqua observations than with Terra. The Terra overpass time at the Equator is around 10:30 local solar time in its descending mode and around 22:30 local solar time in its ascending mode. The Aqua overpass times at the Equator are around 13:30 (01:30) local solar time in ascending (descending) mode.

The different values for maximum injection obtained with Aqua and Terra observations show that the two methods reproduce the maximum of the diurnal cycle of fire activity during the early afternoon well. With Terra observations, a number of cases with a very stable PBL give very low maximum injection heights; this is more marked for the PRM. With Aqua, the number of such cases is smaller.

\subsection{Comparison of the two injection height data sets}

The extended version of GFAS has been run from 1 January 2003 to 1 January 2015. The resulting injection height data sets from IS4FIRES and mean height of maximum injection from the PRM are evaluated in this section.

The average values of the mean height of maximum injection and of the plume top, from the PRM component of
GFAS, and of the injection height from the IS4FIRES component of GFAS are presented in Fig. 4. For the sake of simplicity, these two components will be named "PRM" and "IS4FIRES". Over most of the regions except Siberia, Russia and Ukraine, the injection height from the PRM (i.e. the mean height of maximum injection) is above the injection height from IS4FIRES. The main biomass burning regions, Brazil, Africa (north and south of the Equator), SE Asia and Australia, are prominent on all the plots, with injection heights that are higher than other regions, such as China, India and Central America. The two algorithms estimate the higher injection heights over central Australia, for a limited number of fires, however.

The outputs from IS4FIRES and PRM are compared in Table 1 for the regions of interest defined in Kaiser et al. (2012) (shown in Fig. 1). In addition to the average, the 1st, 5th (median) and 9th deciles are given for all regions. The mean of the PBL height diagnostic from the ECMWF model for grid points that include fires only is also given. The average of the PRM injection heights is globally approximately $150 \mathrm{~m}$ higher than the IS4FIRES injection height. The regional variability is high, with tropical Asia and Europe showing the lowest injection heights on average for the two algorithms, and Australia the highest. The intra-regional variability is much larger for the PRM than for IS4FIRES injection heights: the lowest plumes are much lower with the PRM, and the highest plume much higher as well. This was also shown by Paugam et al. (2015): the PRM seems more able to estimate the higher injection heights. The 9th decile is on average $650 \mathrm{~m}$ higher for the PRM compared to IS4FIRES. Maximum values of injection heights can reach 7 or $8 \mathrm{~km}$ on occasion with the PRM while they very seldom reach $4 \mathrm{~km}$ with IS4FIRES.

This table also confirms that there is a significant statistical link between PBL height and injection heights, more marked with the PRM. The PBL height diagnostic from ECMWF for grid cells with fires show low values for tropical Asia. This is probably because most fires occur quite close to the sea in this region, which mainly comprises Indonesia. The spatial interpolation may thus include PBL height values from over the sea, which are lower than over land because of lower daytime heat flux from the surface. Besides this region, the regions that display the lowest and the highest averages injection heights with the PRM are also the regions with the lowest and highest PBL heights at grid cells with fires. Comparing the 9th decile with PBL height shows that for all regions, the 9th decile of PRM injection heights is significantly above the PBL height diagnostic. This means that with the PRM and for all regions, more than $10 \%$ of fires release their constituents mainly in the free atmosphere. For the IS4FIRES parameterisation, this is true only for some specific regions: Australia, South America, northern Asia and tropical Asia. For the most active biomass burning region globally, Africa, north and south of the Equator, the difference between the PRM and IS4FIRES injection heights is significant in terms 

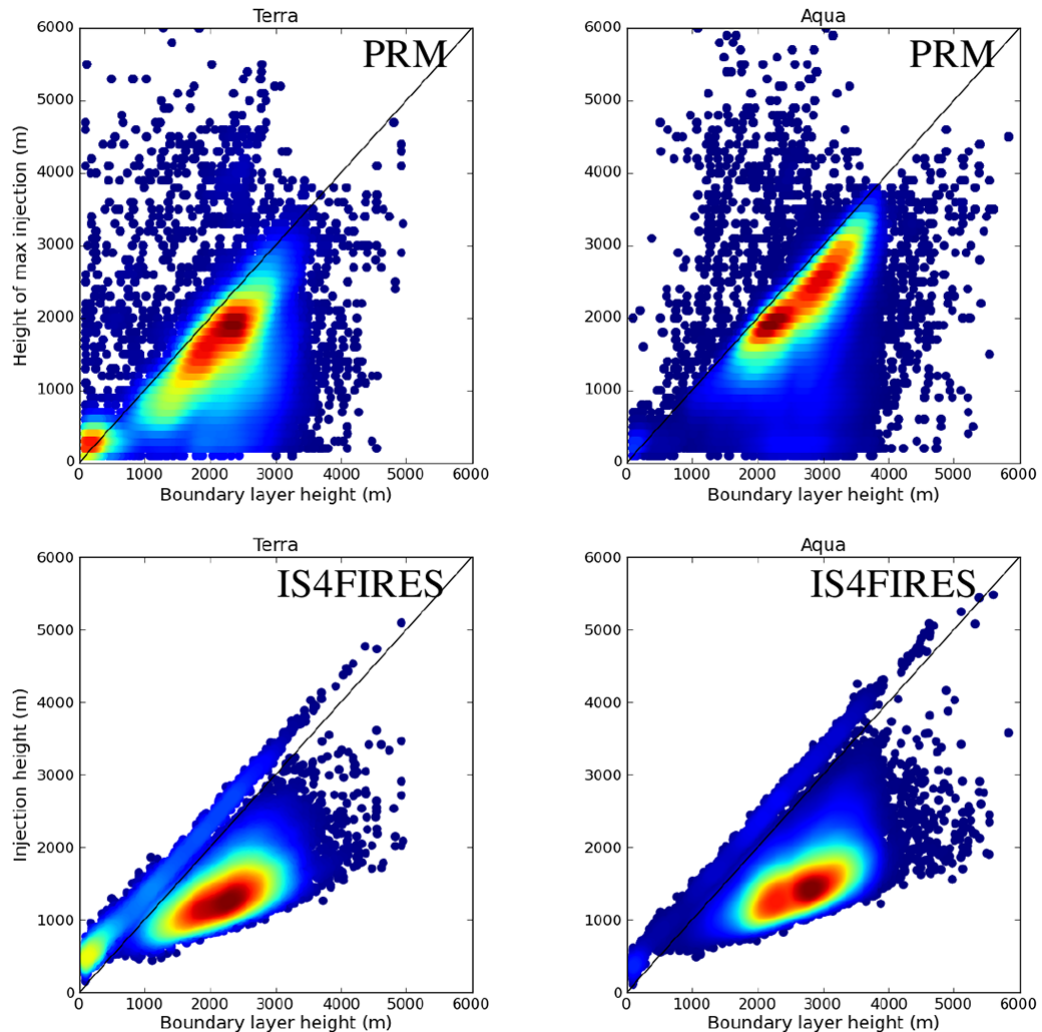

Figure 3. Comparison of the ECMWF boundary layer height diagnostic with the raw height of maximum injection from the PRM (top) and from the IS4FIRES algorithm (bottom) for the 1 June-1 August 2013 period. Observations used are from Terra (left) and Aqua (right).

Table 1. Statistical analysis of the IS4FIRES and the PRM plume height in GFAS over the period 1 January 2003-1 January 2015, together with the mean of the PBL height diagnostic from the operational ECMWF model at the points where there were fires. All values are in metres and computed for the same fires. Only the non-null values were used in the computation of the statistics. IS4 stands for IS4FIRES parameterisation, PRM for plume rise model.

\begin{tabular}{lrrrrr}
\hline Region name & mean-IS4/PRM & mean PBL h & 1st decile-IS4/PRM & 5th decile-IS4/PRM & 9th decile-IS4/PRM \\
\hline Global & $1377 / 1536$ & 1634 & $792 / 431$ & $1316 / 1460$ & $2026 / 2680$ \\
Australia & $1522 / 1570$ & 1955 & $889 / 465$ & $1465 / 1567$ & $2218 / 2616$ \\
Central America & $1173 / 1164$ & 1620 & $818 / 388$ & $1129 / 1092$ & $1586 / 1963$ \\
Europe & $1021 / 836$ & 1585 & $591 / 245$ & $985 / 740$ & $1490 / 1550$ \\
North America & $1361 / 1193$ & 1611 & $858 / 396$ & $1398 / 1138$ & $1928 / 2018$ \\
Northern Asia & $1179 / 1022$ & 1493 & $741 / 320$ & $1144 / 966$ & $1656 / 1768$ \\
N. Hem. Africa & $1168 / 1309$ & 2054 & $685 / 425$ & $1167 / 1184$ & $1771 / 2333$ \\
S. Hem. Africa & $1272 / 1424$ & 2321 & $801 / 529$ & $1209 / 1359$ & $1814 / 2364$ \\
South America & $1316 / 1375$ & 1809 & $829 / 371$ & $1255 / 1305$ & $1882 / 2406$ \\
Southern Asia & $1105 / 1147$ & 1591 & $788 / 466$ & $1066 / 1096$ & $1472 / 1871$ \\
Tropical Asia & $983 / 1092$ & 1079 & $697 / 404$ & $954 / 916$ & $1306 / 1970$ \\
\hline
\end{tabular}

of the number of fires that release their emissions above the PBL.

This greater variability of the PRM compared to IS4FIRES is also apparent in Fig. 5, which shows global and regional density plots of median injection heights from the PRM versus IS4FIRES. The linear fit between the two sets indicates that for all regions, the extreme values are more extreme with the PRM. For some regions, such as Europe and Northern Hemisphere Africa, the median injection height from the PRM is below $500 \mathrm{~m}$ in many cases. For these two regions, the mean and median of injection heights are significantly lower with the PRM than with IS4FIRES; which shows that this has a strong impact on regional statistics. This plot also 

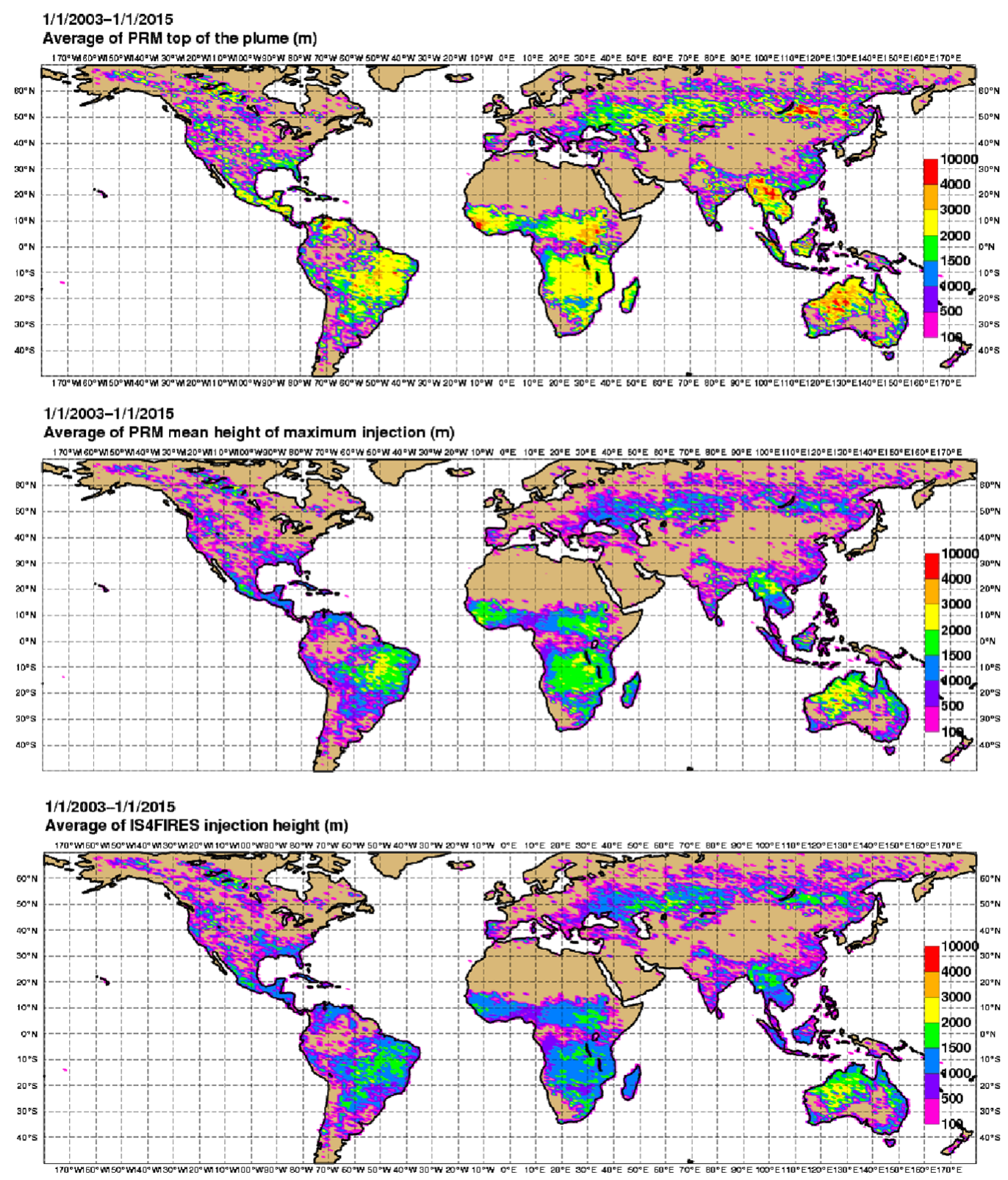

Figure 4. Global average for the 1 January 2003-1 January 2015 period of daily injection heights from GFAS. Top of the plume (top), mean height of maximum injection (middle) from the PRM and injection height estimated with the IS4FIRES parameterisation (bottom). The averages were computed taking into account only non-null values.

highlights the regional variability, which is more marked for the PRM compared to IS4FIRES injection heights.

\subsection{Validation against MISR observations of plume top heights}

In this section, the newly computed injection heights are compared with the MPHP2 data set of injection heights derived from MISR observations for each GFAS grid cell in which both MPHP2 observations and GFAS injection heights are available. By taking into account only the plumes with good and fair retrieval quality, the verification data set is composed of 13454 injection heights. When collocating these observations with the non-null injection heights computed from Terra-based fire observations in GFAS, the sample size is reduced to 4182 , or $31 \%$ of the initial verification data set.

\subsubsection{Global scores}

The global injection height distribution of the MPHP2, PRM and IS4FIRES injection heights is shown in Fig. 6. The val- 


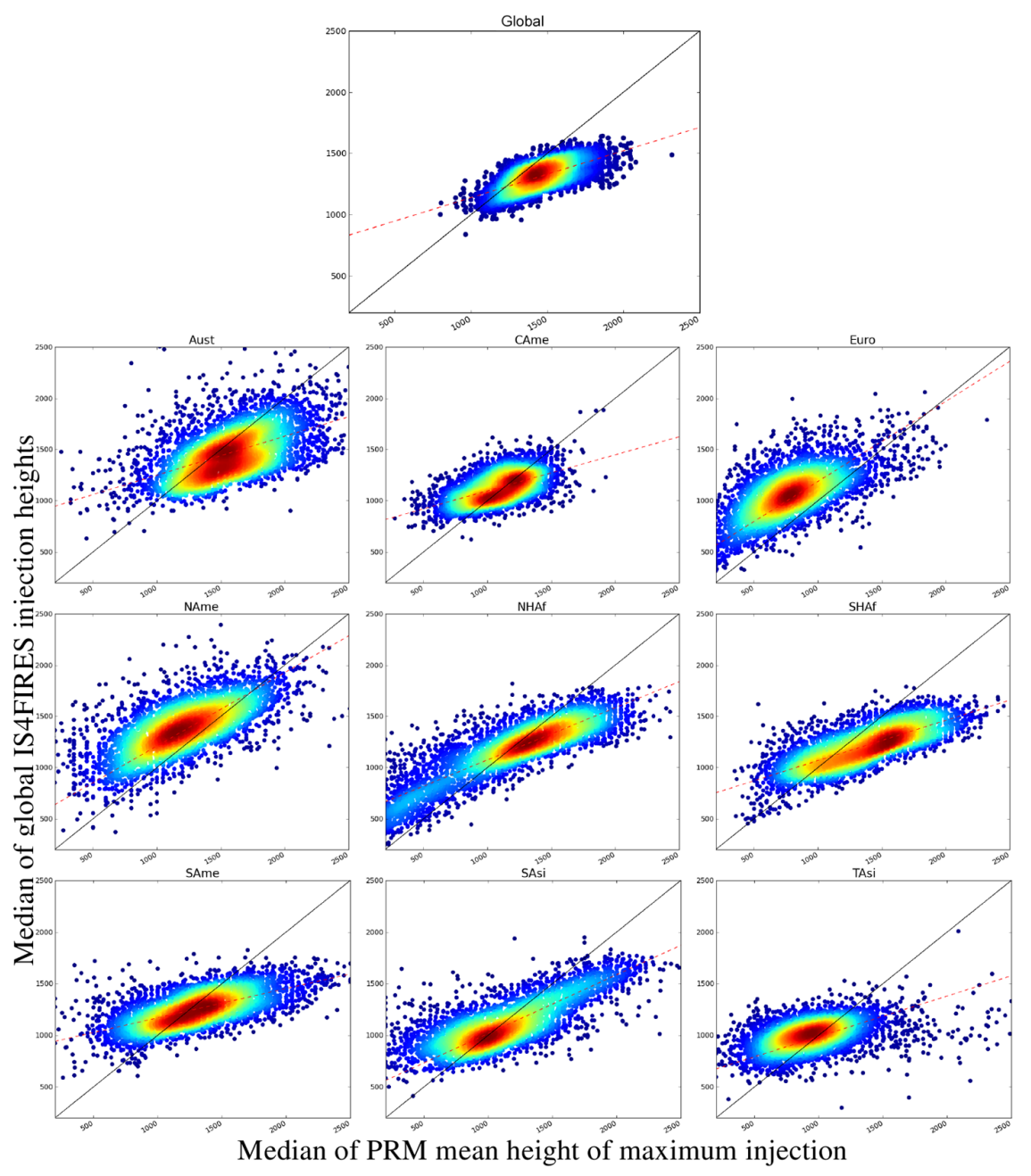

Figure 5. Density plots of global and regional comparison of the median of global IS4FIRES injection height against the median of the global PRM mean height of maximum injection for the period 1 January 2003-1 January 2015. The dashed red lines indicate the best linear fit.

ues are all for fires for which a MPHP2 injection height estimate of fair or good quality is available. The IS4FIRES injection heights are more often closer to the MPHP2 values, especially between 800 and $2000 \mathrm{~m}$, which represents the majority of cases. The PRM shows a significant overestimation of the frequency of injection heights below $500 \mathrm{~m}$; this is especially apparent for very low injection heights $(200 \mathrm{~m})$. These very low values from the PRM should clearly be disregarded. The IS4FIRES parameterisation on the other hand underestimates the number of plumes with injection heights below $1000 \mathrm{~m}$. For injection heights above $2500 \mathrm{~m}$, i.e. in the upper tail of the vertical distribution, the PRM gives a frequency that is closer to observations. These plumes constitute a minority of observed plumes, but they are particularly important in terms of atmospheric composition they are particularly large and subject to long-range transport in the free troposphere.
Figure 7 presents global density plots of MPHP2 injection heights versus IS4FIRES and PRM injection heights from GFAS, and the associated statistical scores are detailed in Table 2. The IS4FIRES injection heights show a small positive bias; this bias is especially marked for observed injection heights that are below $1000 \mathrm{~m}$. On the other hand, for MPHP2 values above $3 \mathrm{~km}$, the IS4FIRES injection heights are often significantly underestimated, by more than $1000 \mathrm{~m}$ in a number of cases. This shortfall of the IS4FIRES parameterisation was already noted in Sofiev et al. (2012) and Veira et al. (2015a). For MPHP2 plumes between 1000 and $2000 \mathrm{~m}$, which represent a majority of observations, the IS4FIRES injection heights are often within $500 \mathrm{~m}$ of the observations.

The larger variability and the more important positive bias of the PRM injection heights are also apparent in Fig. 7 and Table 2. A significant number of plumes are forecasted with injection heights at $200 \mathrm{~m}$, while observations for these 
Table 2. Scores of IS4FIRES/PRM plume height against the MPHP2 data set for the year 2008, for each region defined in Fig. 1 . The "\% inside" score corresponds to the relative fraction of estimated plumes that are within $500 \mathrm{~m}$ of the MPHP2 observations.

\begin{tabular}{lrrrrrr}
\hline Region name & sample size & RMSE-IS4/PRM $(\mathrm{m})$ & bias-IS4/PRM (m) & mean-IS4/PRM (m) & R-IS4/PRM & \% inside-IS4/PRM \\
\hline Global & 4182 & $533 / 955$ & $144 / 239$ & $1619 / 1714$ & $0.45 / 0.31$ \\
Australia & 306 & $652 / 863$ & $120 / 186$ & $1555 / 1620$ & $0.55 / 0.44$ & $57 / 44$ \\
Central America & 151 & $426 / 684$ & $117 / 43$ & $1453 / 1380$ & $0.22 / 0.10$ & $57 / 50$ \\
North America & 251 & $632 / 1071$ & $-69 /-110$ & $1832 / 1791$ & $0.59 / 0.37$ & $63 / 50$ \\
Europe & 196 & $489 / 879$ & $-133 /-96$ & $1596 / 1634$ & $0.41 / 0.33$ & $55 / 42$ \\
North Asia & 997 & $497 / 852$ & $-13 /-73$ & $1626 / 1567$ & $0.47 / 0.32$ & $53 / 45$ \\
North Hem. Africa & 836 & $486 / 1073$ & $180 / 401$ & $1616 / 1836$ & $0.39 / 0.40$ & $64 / 49$ \\
South Hem. Africa & 825 & $631 / 1010$ & $375 / 584$ & $1668 / 1876$ & $0.42 / 0.38$ & $57 / 44$ \\
South America & 520 & $556 / 1108$ & $273 / 424$ & $1585 / 1736$ & $0.47 / 0.30$ & $54 / 40$ \\
South Asia & 90 & $537 / 969$ & $26 / 63$ & $1307 / 1339$ & $0.46 / 0.40$ & $48 / 61$ \\
Tropical Asia & 11 & $297 / 1670$ & $-182 / 923$ & $1357 / 2462$ & $0.14 / 0.13$ \\
\hline
\end{tabular}

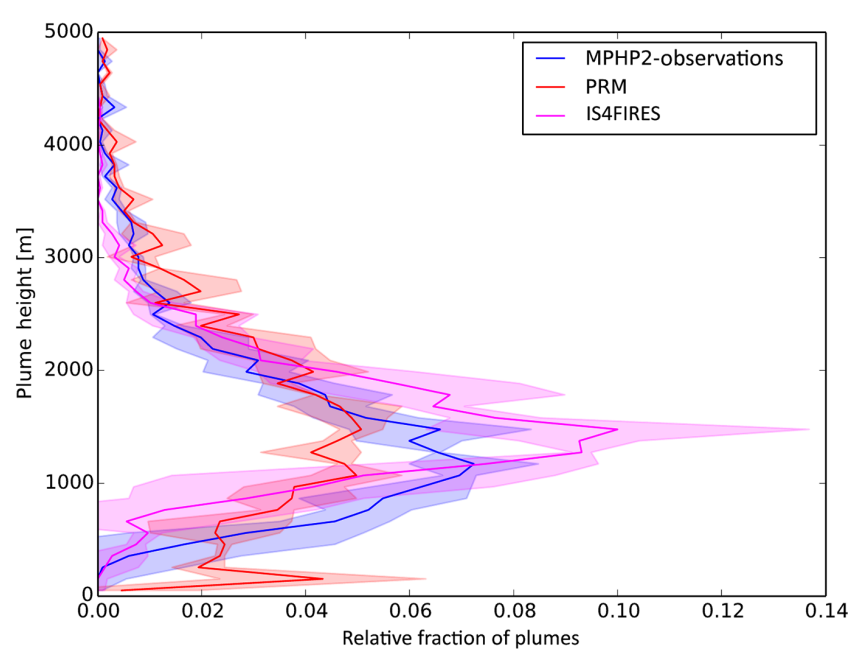

Figure 6. Global distribution of injection height from IS4FIRES and mean height of maximum injection from the PRM (for fires with MPHP2 observations), and of MPHP2 observations for 2008. Shading represents uncertainties of $200 \mathrm{~m}$ in the plume height observations and parameterisations. The sum over the vertical of the relative fractions is 1 for all curves.

plumes range from 500 to $2500 \mathrm{~m}$. This brings a small degradation of the RMSE of the PRM, which is nearly two times larger than the RMSE of IS4FIRES injection heights. The PRM is more able to estimate larger injection heights as compare to the IS4FIRES parameterisation, and a larger fraction of the observed injection heights above $3 \mathrm{~km}$ is well forecasted. However, the majority of injection heights estimated by the PRM to be larger than $3 \mathrm{~km}$ correspond to MPHP2 values well below $2500 \mathrm{~m}$. This is consistent with the findings of Val Martin et al. (2012) who found, with an earlier version of the PRM, that $44 \%$ of the plumes are incorrectly estimated to reach the free troposphere.

\subsubsection{Regional scores}

Global and regional scores are summed up in Table 2. The proportion of estimated plumes that fall within $500 \mathrm{~m}$ of the observations is also displayed. Globally and for all regions, 55 to $65 \%$ of injection heights from IS4FIRES fall within $500 \mathrm{~m}$ of the observations compared to 40 to $50 \%$ for PRM injection heights. Correlation between estimations and observations is also higher for IS4FIRES's injection heights, with values ranging from 0.4 to 0.55 for the correlation coefficient compared to 0.3 to 0.4 for PRM injection heights. The figures for IS4FIRES injection heights are close to the results of Sofiev et al. (2012); the fraction of plumes that fall within $500 \mathrm{~m}$ of the observations are a bit lower.

The lower scores of the PRM injection heights are associated with a much larger RMSE and bias, globally and for all regions. The two algorithms show a correlation in both bias and RMSE. The regions with maximum and minimum bias and error are the same for both algorithms, with larger values for the PRM. This is because the errors are larger for higher injection heights in both calculations.

\subsubsection{Scores per biome type}

The MPHP2 data set also includes the MODIS landcover-type product following the International GeosphereBiosphere Programme (IGBP) classification (Channan et al., 2014). Scores for each IGBP biome type are shown in Table 3. They help understand the strengths and weaknesses of each algorithm. The PRM shows a large bias of $664 \mathrm{~m}$ for evergreen broad-leaf forests, and a bias of more than $350 \mathrm{~m}$ for savannas and woody savannas. This could come from the fact that the parameters of the PRM were derived by optimisation using a small number of plumes in North America (Paugam et al., 2015), which may not at all include plumes over this kind of land cover. For these biome types, which represent more than half of the MPHP2 data set, the RMSE is also very large for the PRM. 

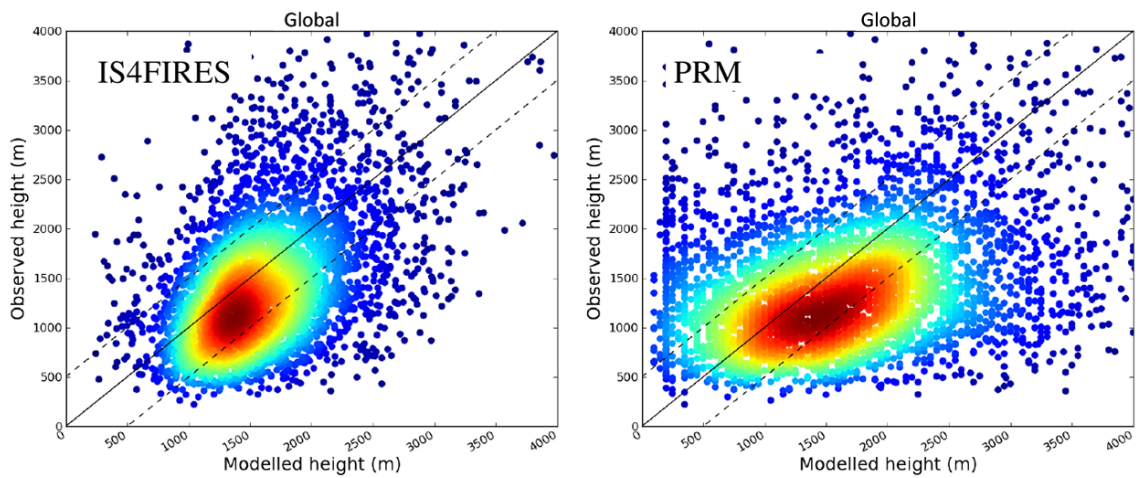

Figure 7. Density plots of global comparison of the MPHP2 observations of plume height in 2008 against the IS4FIRES (left) and the PRM (right) injection heights of GFAS. MPHP2 observations with "good" and "fair" quality flags were used. The dashed lines delineate the area in which the GFAS injection heights are within $500 \mathrm{~m}$ of observations.

Table 3. Scores of IS4FIRES/PRM plume height against the MPHP2 data set for the year 2008, for each IGBP biome type. The "\% inside" score corresponds to the relative fraction of estimated plumes that are within $500 \mathrm{~m}$ of the MPHP2 observations.

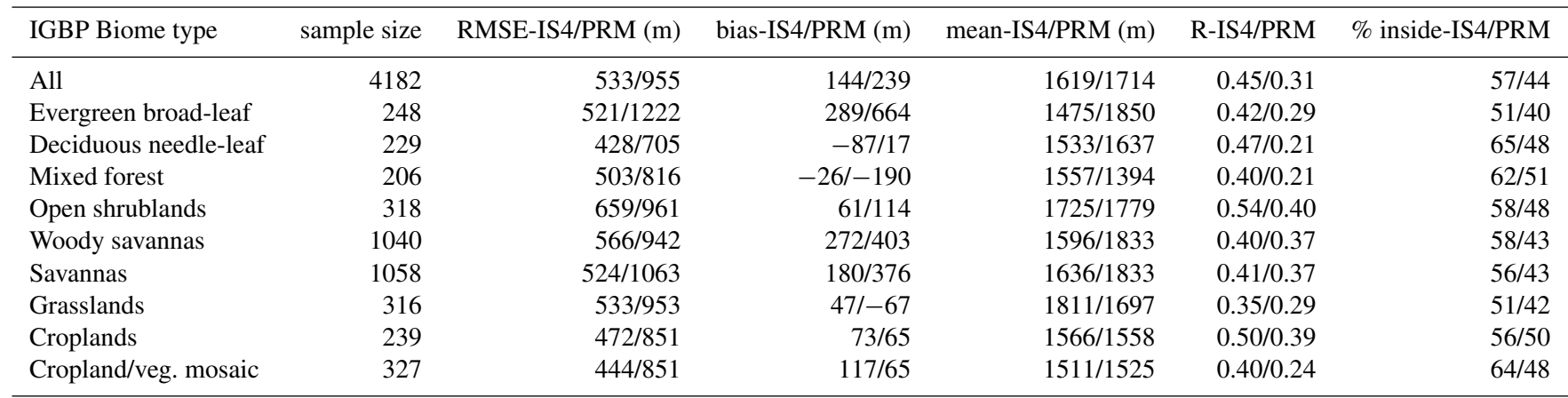

The RMSE and bias are both significantly lower for IS4FIRES injection heights, for all biome types. The variability depending on the biome type is also lower for IS4FIRES. For both injection heights, the best results are achieved for fires occurring in deciduous needle-leaf forest areas, i.e. boreal fires. For the PRM, optimisation of the parameters was done on fires occurring just over such land covers.

\subsection{Discussion}

There are three sources of errors in the injection height estimates that were assessed in this study (besides possible errors on the verification data set):

- uncertainties on the MODIS satellite products that are used as input,

- uncertainties on the ECMWF profiles that are used to provide information on the environment,

- and finally, simplifications and/or processes not represented in the algorithms.

These three sources of errors all play a role in the scores. MODIS FRP is often underestimated (Kahn et al., 2008;
Schroeder et al., 2014). This underestimation seems to be more significant for large fires, because of the opacity effect whereby the smoke hinders the remote detection of thermal anomalies at the surface. Veira et al. (2015a) improved scores of another version of IS4FIRES relative to the MPHP data set by applying an empirical FRP correction for plumes higher than a threshold height. This has not been tried yet in this study; however this modification will probably increase the small positive bias against MPHP2 injection heights of the IS4FIRES injection heights. Tests were carried out using the accumulated FRP of the fire cluster instead of the cluster maximum FRP as an input for the IS4FIRES parameterisation. This did not have much impact on the output and the scores, despite a much larger input value for FRP of large fires.

Using additional satellite products, especially from geostationary satellites, can only improve the quality of the injection heights and of the GFAS products as a whole. This would also allow us to describe the diurnal cycle of fires and injection heights. Work is going on to combine the accuracy of low orbit observations with the better time resolution of geostationary products in GFAS (Andela et al., 2015). 

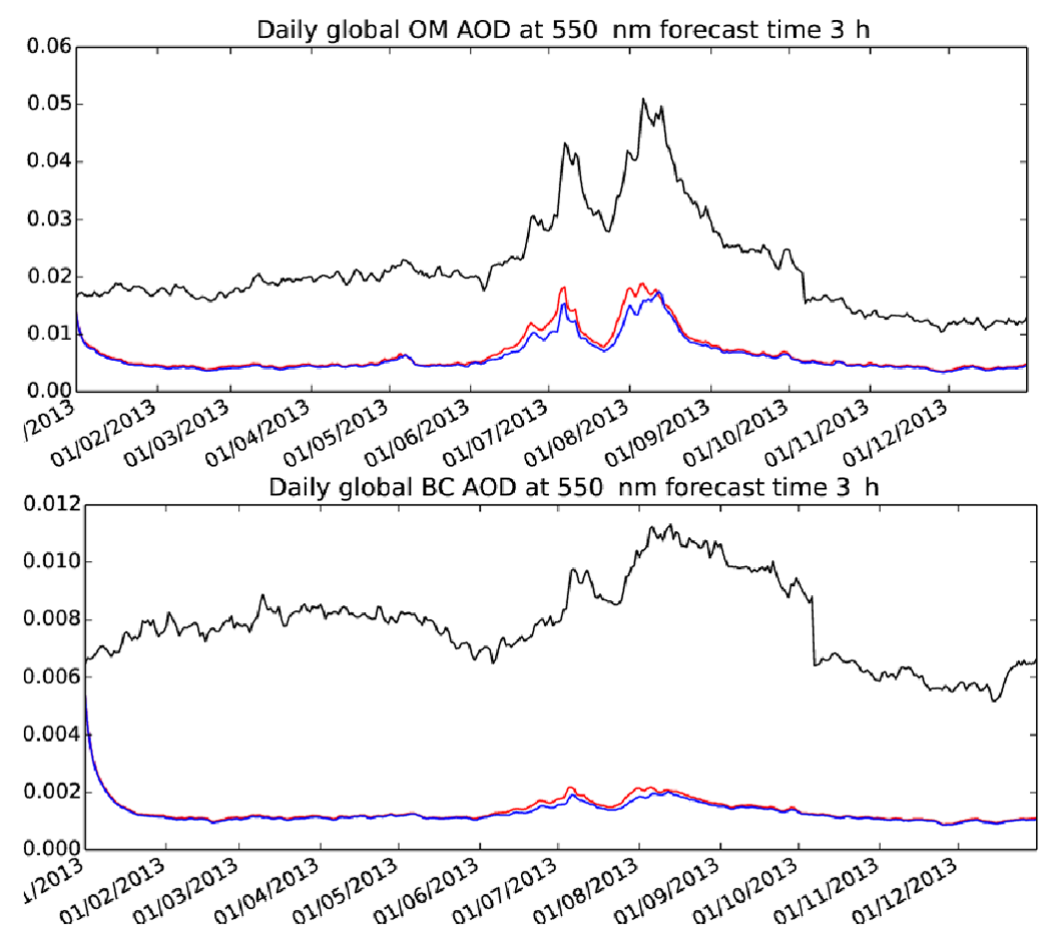

Figure 8. Global optical depth at $550 \mathrm{~nm}$ of organic matter (OM) aerosol (top) and black carbon (BC, bottom) for the year 2013, simulated by C-IFS. The simulation with data assimilation is shown in black (biomass burning emissions are prescribed at the surface), without assimilation and with biomass burning aerosol emissions prescribed at the surface is in blue and at the PRM injection height in red.

The two algorithms are very dependent on the atmospheric profiles provided by the ECWMF. The diagnosed PBL height is of special important since plumes often reach the top of the PBL without breaking through to the free troposphere. Even if the ECMWF diagnostic appears to be of good quality generally (see the studies of Palm et al., 2005 and Flentje, 2014), possible errors will have a large impact on injection height estimates from both algorithms. In particular, given the strong correlation between the PRM injection height and PBL height (see Fig. 3), it is possible that the numerous cases for which the PRM estimates very small injection heights (200-300 m), while the MPHP2 data set gives values from 1000 to $2000 \mathrm{~m}$, correspond to cases where the PBL height was underestimated according to ECMWF. In some cases, especially over Indonesia, some land-sea mask representativity issues arose for the ECMWF PBL height and environment profiles, caused by the coarse $1 \times 1^{\circ}$ grid that was used. The bad scores of the PRM over Indonesia were improved when using a better resolution for the atmospheric environment. The extra computing cost of increasing the resolution of the environment is however too great to consider this option for running GFAS in near-real-time (NRT) mode or to produce climatology. Strada et al. (2013) found a great sensitivity of the PRM to ambient wind and humidity. In this implementation, the atmospheric stability was found to be have the most impact on the output of the PRM.
Also, the fact that the PBL height diagnosis from ECMWF was used in IS4FIRES instead of the PBL height formulations used in Sofiev et al. (2012) and Sofiev et al. (2013) could provide a source of error for this algorithm.

The PRM is a much more complex algorithm than IS4FIRES, using an estimate of fire size as an additional input, and taking into account wind drag, plume microphysics, entrainment and detrainment in its parameterisation. This increased complexity makes it more able to estimate large injection heights; however it also means that it is less robust than IS4FIRES in the sense that it is subject to more sources of uncertainty, notably on fire size. The fact that six parameters (see Appendix A) in its system of equations were fitted from a small number of plumes may have degraded its results, especially for the land cover types that were not taken into account in Paugam et al. (2015). The PRM was also shown to be very sensitive to entrainment (Val Martin et al., 2012), for which there is very little information available.

Additionally for the PRM, the fact that a whole detrainment profile is translated into only three parameters (mean height of maximum of injection, top of the plume, bottom of the plume) leads to an additional source of error. 

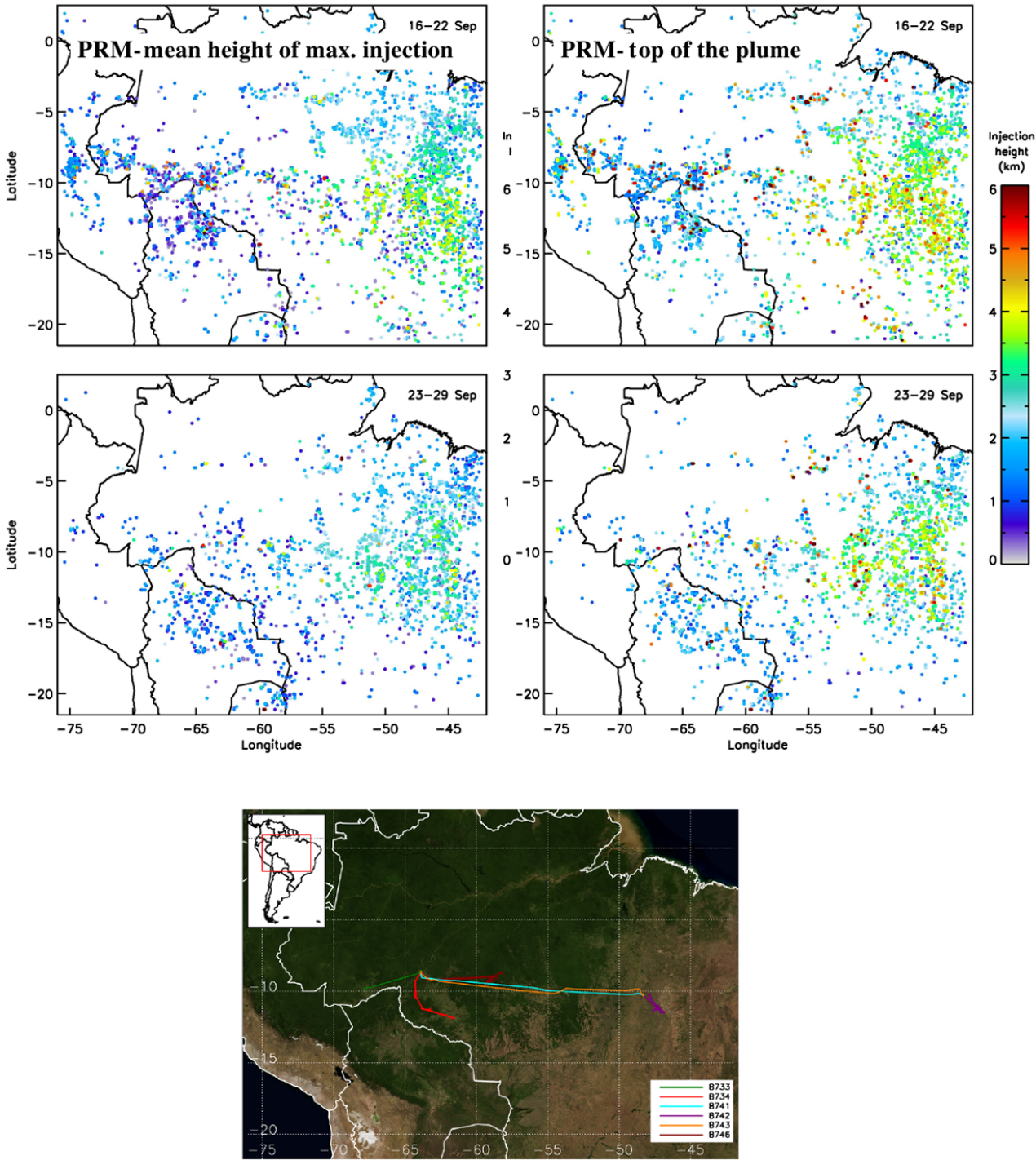

Figure 9. Left: PRM mean height of maximum injection from GFAS, accumulated values from (top) 16 to 22 September 2012 and (middle) 23 to 29 September 2012. Right: PRM top of the plume from GFAS, accumulated values from (top) 16 to 22 September 2012 and (middle) 23 to 29 September 2012. Bottom: ground tracks of the six research flights of the SAMBBA field campaign.

\section{Use of GFAS injection heights in C-IFS}

This chapter presents two case studies for the use of assimilated injection heights from GFAS in C-IFS: the SAMBBA campaign which took place in September 2012 in Brazil, and a series of large fire events in the western USA in August 2013. It should be noted that the comparisons between observations and the model in this section can only be of a qualitative nature. Due to the large range of possible modelling errors (regarding sources, atmospheric transport, aerosol processes, etc.), the use on injection heights is only one of the numerous factors that has an impact on the simulated biomass burning aerosol extinction.

C-IFS used to emit biomass burning aerosols at the surface. The model was modified to allow biomass burning emissions to be injected at the level of the PRM mean height of maximum injection from GFAS. A criterion on the PBL height diagnostic was added to prevent emitting biomass burning aerosols too high at night: the injection height provided by the PRM is used only when the PBL height is above $500 \mathrm{~m}$. The PRM was chosen for a first implementation because it appears to estimate better high injection heights, associated with large fires, which have a more important impact on atmospheric composition. The IS4FIRES injection heights will be used in an upcoming test, since they show better scores overall in comparison with the MPHP2 data set.

When used in C-IFS, the GFAS emissions of biomass burning aerosols are scaled by a factor of 3.4. This value was estimated by Kaiser et al. (2012) by comparing simu- 


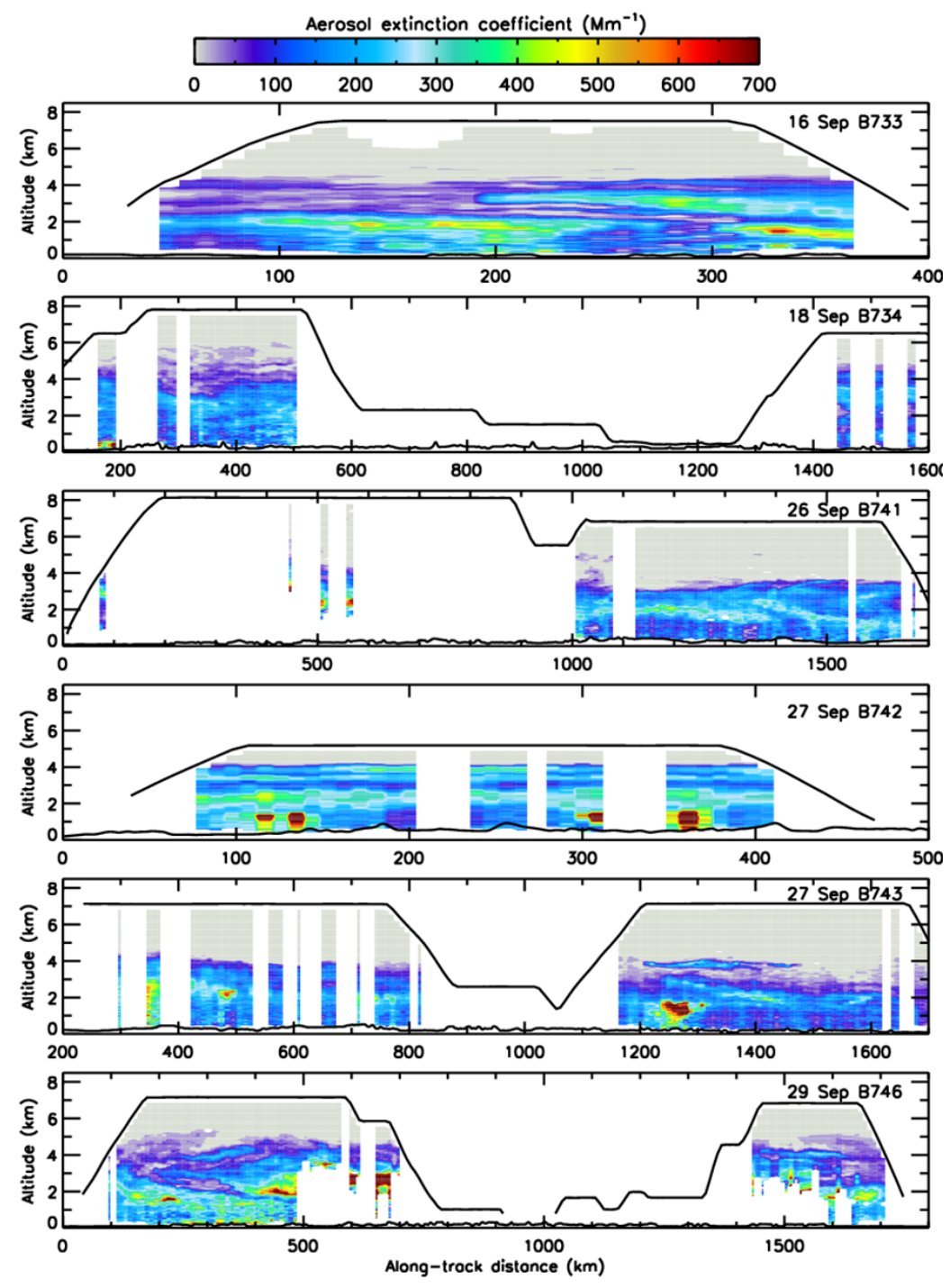

Figure 10. Cross sections of the aerosol extinction at $355 \mathrm{~nm}$ coefficient determined from the lidar for the six research flights with a 1 min integration time. The black lines indicate the aircraft altitude and the surface elevation from a digital elevation model, respectively.

lations with and without data assimilation, both using GFAS for biomass burning sources. The scaling factor was recomputed using the same method but for organic matter (OM) and black carbon (BC) separately (rather than for the sum of these two) using 1-year C-IFS runs with and without data assimilation, with biomass burning aerosol emissions prescribed at the surface and at the mean height of maximum injection provided by the PRM. The result is shown in Fig. 8 . The use of injection heights has an overall small impact on $\mathrm{OM}$ and BC optical depths simulated by C-IFS; however it is more significant when large fire events occur, such as in summer 2013. The optical depths of both OM and BC are higher when emissions are at an altitude rather than at the surface. This can be explained by the fact that aerosols emitted at the surface are immediately subjected to dry deposition, which is not the case when they are emitted higher up. This increases residency time for aerosols that are emitted at an altitude in contrast to aerosols emitted at the surface.

For OM, the scaling factor with emissions prescribed at the surface varies from 2.7 to 5 , the smaller values corresponding to large fire events. The global average is 3.2. For BC, the same scaling factor varies from 4.9 to 7 , with a 6.1 average. With emissions at the mean height of maximum injection, the global average for $\mathrm{OM}$ and $\mathrm{BC}$ scaling factors are 3.0 and 5.9 respectively, to be compared against values of 3.2 and 6.1 when biomass burning emissions are prescribed at the surface.

These results are applicable only to GFAS biomass burning emissions used in the C-IFS model: other models also use a scaling factor for biomass burning emissions, but their values are different: 1.7 for the Met Office Unified Model limited-area model configuration over South America that 
Table 4. Research flights of the SAMBBA field campaign considered in this article. Time is UTC.

\begin{tabular}{llllrr}
\hline Flight & Date & Take-off & Landing & Latitude & Longitude \\
\hline B733 & 16 Sep & Rio Branco, 13:51 & Porto Velho, 14:45 & $8.9-9.8^{\circ} \mathrm{S}$ & $64.5-67.6^{\circ} \mathrm{W}$ \\
B734 & 18 Sep & Porto Velho, 12:05 & Porto Velho, 16:01 & $8.9-11.9^{\circ} \mathrm{S}$ & $61.6-64.4^{\circ} \mathrm{W}$ \\
B741 & 26 Sep & Porto Velho, 12:53 & Palmas, 16:08 & $8.8-10.2^{\circ} \mathrm{S}$ & $48.7-63.9^{\circ} \mathrm{W}$ \\
B742 & 27 Sep & Palmas, 12:52 & Palmas, 16:17 & $10.2-11.5^{\circ} \mathrm{S}$ & $46.8-48.1^{\circ} \mathrm{W}$ \\
B743 & 27 Sep & Palmas, 18:08 & Porto Velho, 21:34 & $9.0-10.2^{\circ} \mathrm{S}$ & $48.4-63.6^{\circ} \mathrm{W}$ \\
B746 & 29 Sep & Porto Velho, 12:54 & Porto Velho, 16:38 & $8.7-9.4^{\circ} \mathrm{S}$ & $58.2-63.7^{\circ} \mathrm{W}$ \\
\hline
\end{tabular}

was used for the SAMBBA campaign, which also made use of GFAS emissions (Kolusu et al., 2015; Marenco et al., 2016); GEOS-5 uses scaling factors for GFED emissions of 1.8 for savanna and grassland, 2.5 for tropical forest and 4.5 for extratropical forest (Colarco, 2011).

\subsection{SAMBBA field campaign}

The South AMerican Biomass Burning Analysis (SAMBBA) campaign was an intensive field campaign which took place in September-October 2012 in Brazil and aimed at investigating the properties of biomass burning aerosols over the Amazon basin. The main biomass burning season occurs there during July-October, when deforestation fires and agricultural burning are frequent. Marenco et al. (2016) analysed lidar observations of smoke aerosols from six flights of the Facility for Airborne Atmospheric Measurements (FAAM) BAe-146 research aircraft. The ground tracks of the considered flights are shown in Fig. 9 and Table 4, reproduced from Marenco et al. (2016). The flights took place during intense biomass burning episodes in the east of the Amazon Basin. Figure 9 shows the PRM top of the plume and mean height of maximum injection from GFAS for the 16 to 29 September 2012 period. The first period, 16-22 September, is characterised by intense fires, with mean heights of maximum injection often reaching more than $4 \mathrm{~km}$ between 10 and $15^{\circ} \mathrm{S}$ and $45-55^{\circ} \mathrm{W}$, and the top of the plume is estimated at more than $5 \mathrm{~km}$ for some fires in this box.

The cross sections of the aerosol extinction coefficient from the lidar observations for the six considered research flights are presented in Fig. 10. All of the six flights show enhanced extinction that has been ascribed to biomass burning, with smoke layers lying at altitudes varying from 2 to $4 \mathrm{~km}$. Extinction profiles from several flights (B733 and B741 especially) show two or more distinct aerosol layers, which may originate from distinct fires. The elevation of the observed aerosol layers is close to the mean heights of maximum injection provided by GFAS in the region, i.e. between 3 and $4 \mathrm{~km}$ generally.

As detailed in Marenco et al. (2016), the observed profiles of aerosol extinction were compared against model predictions from the Met Office Unified Model (MetUM) and C-IFS. The results from the MetUM are presented and analysed in Marenco et al. (2016). Figure 11 shows the simulated extinction profiles from C-IFS along the flight track, with biomass burning aerosols injected at the surface and at the PRM mean height of maximum injection provided by GFAS.

Except for flight B741, the aerosol extinction is larger when the biomass burning aerosol are injected at an altitude, for the same reasons as explained previously.

Compared to the observations, using the PRM injection height from GFAS seems to bring an improvement into the forecasts of the aerosol extinction profiles for flights B742, B743 and also B746. For these flights, the observed layers of aerosols at $4 \mathrm{~km}$ (B742), $2 \mathrm{~km}$ (B743) and $2.5 \mathrm{~km}$ (B746) are better represented when using injection heights, while they are either nearly absent (B742) or underestimated (B743 and B744) when biomass burning aerosols are emitted at the surface. For flight B742, the modified model is able to forecast the two aerosol layers that were observed. For flights B734 and B741, there is no discernible improvement or degradation while for flight B733, the use of injection heights increased the simulated aerosol burden in the smoke plume between 2 and $3 \mathrm{~km}$ beyond the observed values.

\subsection{SEAC4RS field campaign}

In the framework of the Studies of Emissions, Atmospheric Composition, Clouds and Climate Coupling by Regional Surveys (SEAC4RS) field campaign, the National Aeronautics and Space Administration (NASA) operates a DC-8 aircraft to sample the smoke plumes from fires in the continental United States. Aerosol extinction was remotely sensed using a combined High Spectral Resolution Lidar (HSRL, Hair et al., 2008) at $532 \mathrm{~nm}$ and Ozone Differential Absorption Lidar at $290 \mathrm{~nm}$ (DIAL, Browell et al., 1983). Measurements here focus on the aerosol measurements from the HSRL. These observations were used for the studies of the Rim Fire, which occurred in late August 2013 in California (Peterson et al., 2015), and were used to derive fire emissions using inversion techniques (Saide et al., 2015).

Here, we focus on a single flight from the DC-8 on $19 \mathrm{Au}-$ gust 2013. The track of the flight and the observed height of the mixed layer are shown in Fig. 12. The cross section of the aerosol extinction at $532 \mathrm{~nm}$ observed by the DIAL-HSRL is presented in Fig. 13a. Its most distinct feature is a series of elevated biomass burning aerosol layers between 4 and $6 \mathrm{~km}$ high, caused by large fires raging in the north-western United 


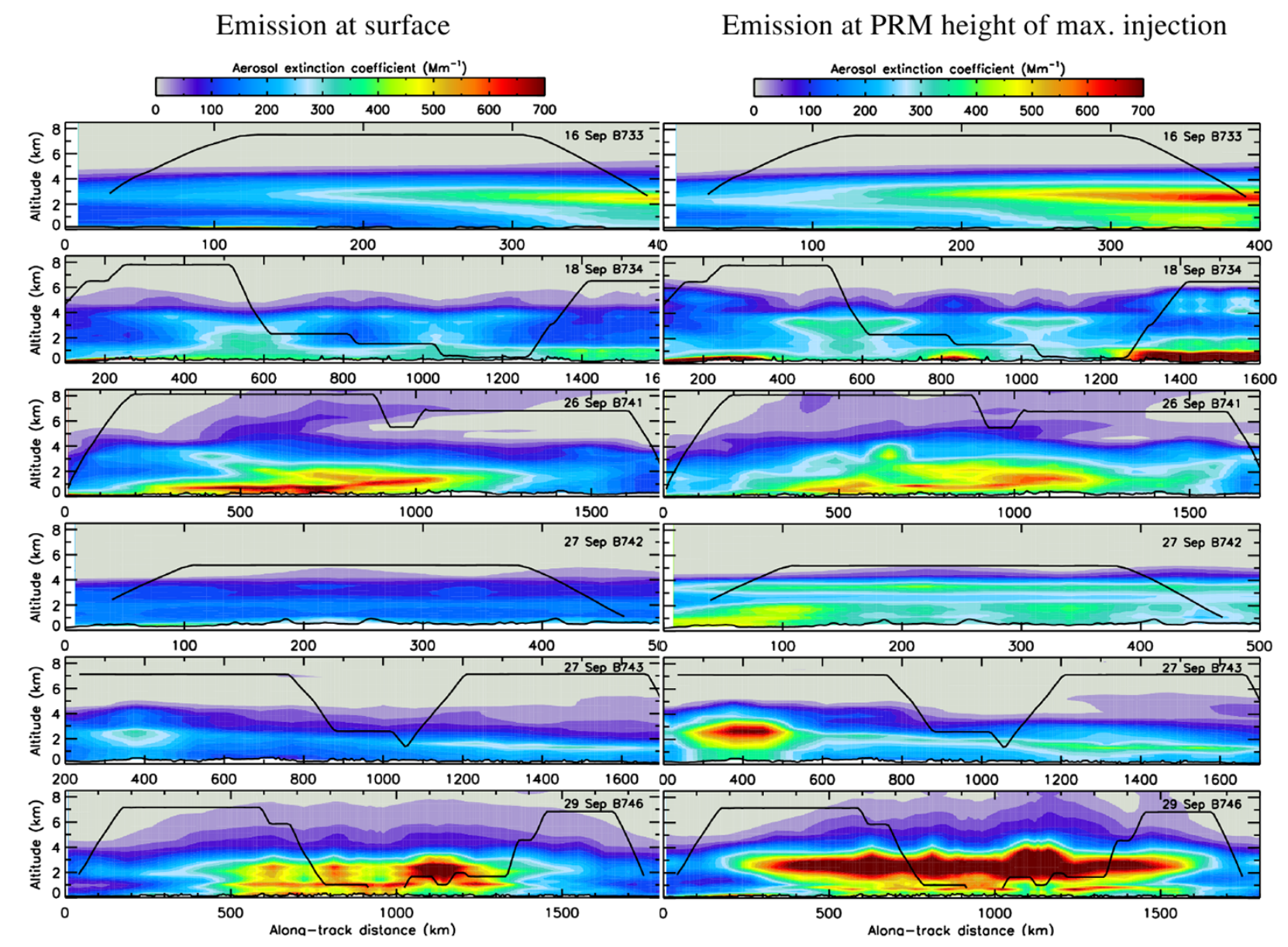

Figure 11. Cross sections of the aerosol extinction coefficient at $532 \mathrm{~nm}$ estimated from the C-IFS along the tracks of the six research flights. Biomass burning aerosols are emitted at the surface (left) and at the PRM mean height of maximum injection provided by GFAS (right).

States. Most of the aerosol burden lies above the top of the PBL, which was between 1 and $1.5 \mathrm{~km}$.

The C-IFS forecasting system was run with biomass burning aerosols emissions prescribed at the surface (13b) and at the PRM mean height of maximum injection from GFAS (Fig. 13c). The extinction resulting from the biomass burning is higher throughout the sampling regions when the injections heights were provided by GFAS compared to emitting at the surface. The difference is especially important for altitudes between 2 and $6 \mathrm{~km}$ at 16:00 $\left(35^{\circ} \mathrm{N}\right)$, around $2 \mathrm{~km}$ between 18:00 and 19:00 $\left(43-45^{\circ} \mathrm{N}\right)$ and around $4 \mathrm{~km}$ between 20:00 and 22:00 $\left(35-40^{\circ} \mathrm{N}\right)$. The simulated values from C-IFS with an injection at the surface underestimated aerosol extinction at altitudes higher than $3-4 \mathrm{~km}$ and sometimes overestimated extinction close to the surface. When using injection heights from GFAS, the smoke layer at higher altitudes is slightly better represented, but the overestimation close to the surface is also larger. The elevated layer of aerosols around $6 \mathrm{~km}$ is not captured by either simulation, which can be caused by errors either in the sources or in the transport and evolution of these smoke plumes.

\section{Conclusions}

Two existing algorithms estimating fire injection heights have been embedded into the GFAS system: the IS4FIRES parameterisation and the plume rise model. The new GFAS version provides daily global fire emissions and injection heights at a resolution of $0.1^{\circ}$. It uses FRP from MODIS and atmospheric profiles from the operational ECMWF model as input. GFAS has been run for the period 2003-2014, and is now running in near-real-time to provide biomass burning emissions for the C-IFS model.

The validation of the injection heights from GFAS against the MPHP2 data set of plume heights observed by MISR show that both algorithms are suitable for plume height estimation, albeit with particular strengths in different respects: the IS4FIRES injection heights achieves better bias and RMSE scores globally and locally, while the PRM appears to represent large injection heights more accurately and to better reproduce the variability of injection heights. Inaccuracies in the input data obviously have an impact on the scores. This is thought to be particular relevant in the 


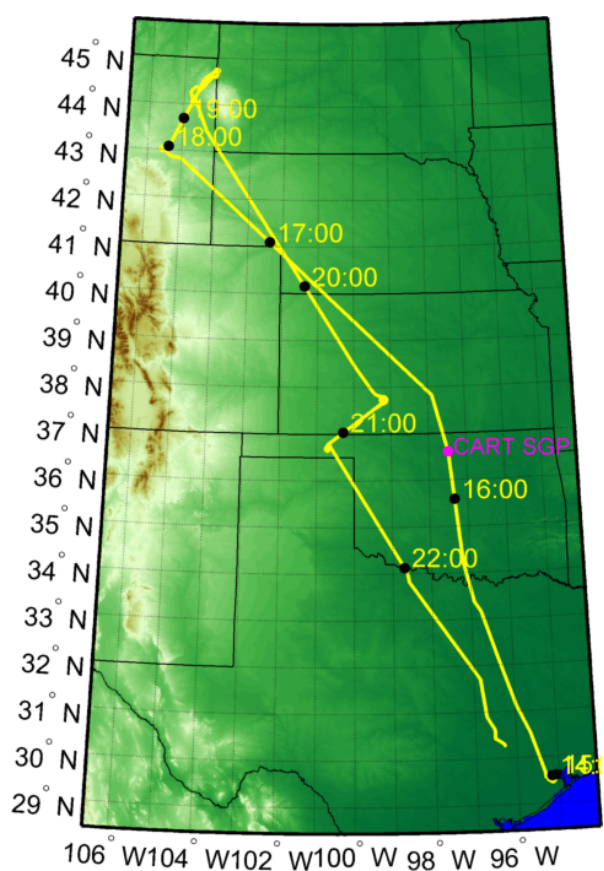

Figure 12. Ground tracks for the 19 August 2013 research flight of the SEAC4RS field campaign, in the southern USA. CART SGP stands for the Cloud and Radiation Testbed (CART) Southern Great Plains (SGP) site.

cases of the planetary boundary layer height diagnostic from ECMWF and a FRP underestimation for particularly large fires, where the MODIS Collection 5 products are known to have larger omission errors due to thick smoke being erroneously classified as cloud. To mitigate these errors, two data sets can also be used together in an optimal combination, with a larger variability than the IS4FIRES data set and a smaller mean error and bias than the PRM data set.

The use of injection heights from GFAS for biomass burning emissions has been implemented in the global atmospheric composition model C-IFS. The scaling factors that are used in C-IFS for biomass burning emissions of black carbon and organic matter were recomputed, with and without using injection heights; they showed little variation when the injection heights from GFAS are used. The new system was run and evaluated for two particular fire situations; the use of injection heights brought model profiles of aerosol extinction generally closer to observations compared to a simulation with emission injection prescribed at the surface. The forecast of high (i.e. above $4 \mathrm{~km}$ of altitude) plumes in particular seems to be improved by using injection heights in the C-IFS system. (a)

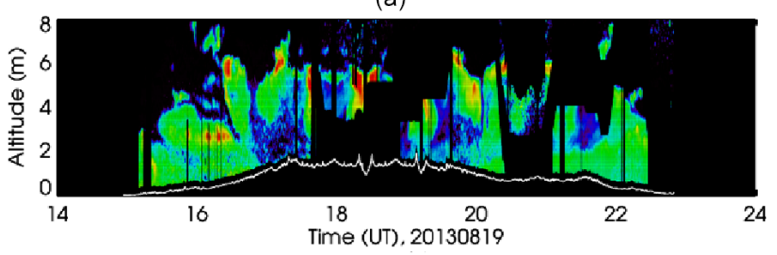

(b)

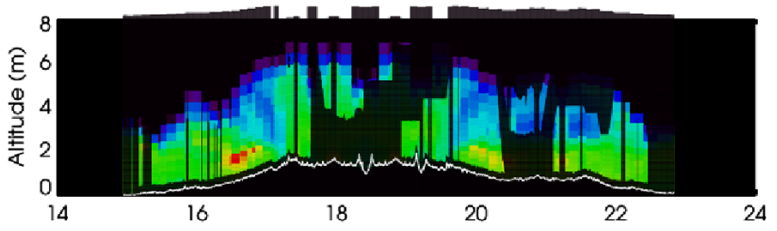

(c)

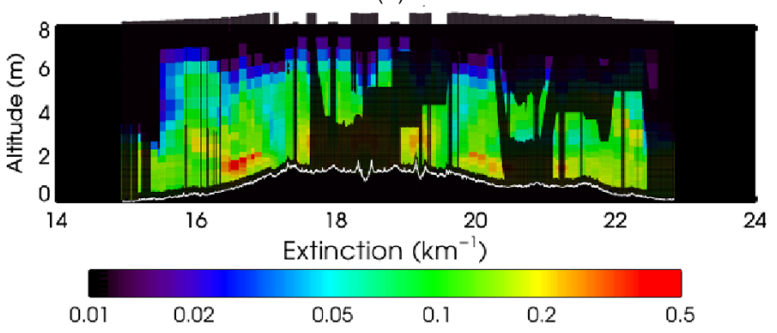

Figure 13. Cross sections of the aerosol extinction at $532 \mathrm{~nm}$; (a) observed along the tracks of the research flights of SEAC4RS of 19 August 2013; (b) C-IFS forecast with biomass burning aerosols emitted at surface and (c) at the PRM mean height of maximum injection provided by GFAS.

The GFAS data set of injection height information (and emission fluxes) is publicly available at the CAMS-GFAS data server at http://apps.ecmwf.int/datasets/data/cams-gfas. It can serve a variety of purposes, from the study of past fires to global atmospheric composition monitoring within the CAMS project, for example. It can also provide input within the framework of model intercomparison projects such as the Aerosol Comparisons between Observations and Models (AEROCOM) project.

\section{Data availability}

The two injection heights data sets are publicly available the CAMS GFAS web page: http://apps.ecmwf.int/datasets/data/ cams-gfas. 


\section{Appendix A: Summary of differences between PRMv0 and PRMv2}

Please refer to Freitas et al. (2007) and Freitas et al. (2010) for a detailed description of the basic PRMv0 equations. The main changes of PRMv2, compared to PRMv0, are described in Paugam et al. (2015). They consist of the addition of a mass conservation equation and a new scheme for plume entrainment and detrainment.

In PRMv0, plume entrainment is the sum of lateral entrainment and dynamical entrainment. Lateral entrainment is parameterised as a function of fire radius $R$ and vertical velocity $w$ (both prognostic variables of the model):

$\gamma_{\text {entr }}=2 \frac{\alpha}{R}|w|$,

where $\alpha$ is a fitting parameter. "Dynamic entrainment" is formulated as follows:

$\delta_{\text {entr }}=2 \frac{1}{\pi R}\left(u_{\mathrm{e}}-u\right)$,

where $u$ is the horizontal velocity at the centre of the plume and $u_{\mathrm{e}}$ is the horizontal velocity of the environment. Plume detrainment is not taken into account.

In the PRMv2, entrainment and detrainment are parameterised as a function of buoyancy and vertical velocity following Pergaud et al. (2009), using a set of four parameters $C_{\epsilon}, C_{\delta}, C_{\epsilon, \text { dyn }}, C_{\delta \text {,dyn }}$, where the $\epsilon$ subscript stands for entrainment and $\delta$ for detrainment.

$\epsilon=\max \left(0, C_{\epsilon} \frac{B}{w^{2}}\right)+C_{\epsilon, \mathrm{dyn}} \frac{1}{w} \frac{\mathrm{d} u}{\mathrm{~d} z}$

$\delta=\max \left(0, C_{\delta} \frac{B}{w^{2}}\right)+C_{\epsilon, \mathrm{dyn}} C_{\delta, \mathrm{dyn}} \frac{1}{w} \frac{\mathrm{d} u}{\mathrm{~d} z}$,

where $B$ is the buoyancy. These 4 parameters, in addition to the $\beta$ parameter that links CHF and FRP, as well as another parameter used at initialisation, need to be fitted using MISR observations. This is done in Paugam et al. (2015) by using a selection of 38 particularly well-characterised plumes over North America from the MPHP data set. These plumes satisfy all the following conditions:
Table A1. Optimal value of the input parameters of the PRMv2 model.

\begin{tabular}{lr}
\hline Parameter & Optimal value \\
\hline$\alpha$ & 0.039 \\
$C_{\epsilon}$ & 1.98 \\
$C_{\delta}$ & -9.78 \\
$C_{\epsilon \text {,dyn }}$ & 1.88 \\
$C_{\delta \text {,dyn }}$ & 8.37 \\
$\beta$ & 0.88 \\
\hline
\end{tabular}

- Fires are not over agricultural land.

- The mismatch between ECMWF winds and winds retrieved in MPHP is small.

- There is a limited number of fire clusters near the plume's origin.

- A plume is clearly and visibly observed.

- The plume is in a steady state, i.e. not in a development or dying out stage.

The parameter-fitting procedure uses a simulating annealing algorithm and a Markov chain Monte Carlo uncertainty test. Table A1 summarises the results of the optimisation step for the six parameters. A value of 1 is used for the $\beta$ parameter for simplicity's sake and because the confidence interval provided by the Monte Carlo uncertainty test was quite large for this particular parameter.

In PRMv2, mass conservation is described by the following equation:

$\partial_{t} \zeta=-\partial_{z}(w \zeta)+w(\epsilon-\delta)$,

where $\zeta=\rho R^{2}$ can be interpreted as the mass per altitude metre, with $\rho$ being the air density and $R$ the radius of the plume. 
Competing interests. The authors declare that they have no conflict of interest.

Acknowledgements. The authors wish to thank NASA for providing the MODIS data, and Charles Ichoku for providing Fig. 2 reproduced from Ichoku and Ellison (2014).

The IS4FIRES algorithm was developed within the IS4FIRES project of the Academy of Finland.

Airborne data from the SAMBBA field campaign were obtained using the BAe-146-301 Atmospheric Research Aircraft (ARA) flown by Directflight Ltd and managed by the Facility for Airborne Atmospheric Measurements (FAAM), which is a joint entity of the Natural Environment Research Council (NERC) and the Met Office.

Support for the DIAL/HSRL operations and measurements during the SEAC4RS field campaign was provided by NASA Headquarter's Tropospheric Chemistry, Radiation Sciences, and Upper Atmospheric Research Programs. Support for the development and addition of the HSRL capability was provided by the NASA Airborne Instrument Technology Transition Program.

This research was supported by the EU Seventh Research Framework Programme (MACC-III project, contract number 283576).

Edited by: A. Baklanov

Reviewed by: S. R. Freitas and two anonymous referees

\section{References}

Achtemeier, G. L., Goodrick, S. A., Liu, Y., Garcia-Menendez, F., Hu, Y., and Odman, M. T.: Modeling smoke plume rise and dispersion from southern United States prescribed burns with daysmoke, Atmosphere, 2, 358-388, doi:10.3390/atmos2030358, 2011.

Ackerman, T. P. and Toon, O. B.: Absorption of visible radiation in atmosphere containing mixtures of absorbing and non-absorbing particles, Appl. Optics, 20, 3661-3667, 1981.

Andela, N., Kaiser, J. W., Heil, A., Van Leeuwen, T. T., van der Werf, G. R., Wooster, M. J., Remy, S., and Schultz, M. G.: Assessment of the Global Fire Assimilation System (GFASv1), available at: https://gmes-atmosphere.eu/documents/ maccii/deliverables/fir (13 July 2016), 2013.

Andela, N., Kaiser, J. W., van der Werf, G. R., and Wooster, M. J.: New fire diurnal cycle characterizations to improve fire radiative energy assessments made from MODIS observations, Atmos. Chem. Phys., 15, 8831-8846, doi:10.5194/acp-15-88312015, 2015.

Andreae, M. O. and Merlet, P.: Emission of trace gases and aerosols from biomass burning, Global Biogeochem. Cy., 15, 955-966, 2001.

Andreae, M. O., Rosenfeld, D., Artaxo, P., Costa, A. A., Frank, G. P., Longo, K. M., and Silva-Dias, M. A. F.: Smoking rain clouds over the Amazon, Science, 303, 1337-1342, doi:10.1126/science.1092779, 2004.

Benedetti, A., Morcrette, J.-J., Boucher, O., Dethof, A., Engelen, R. J., Fisher, M., Flentje, H., Huneeus, N., Jones, L., Kaiser, J. W., Kinne, S., Mangold, A., Razinger, M., Simmons, A. J., and Suttie, M.: Aerosol analysis and forecast in the European Centre for Medium-Range Weather Forecasts Integrated Forecast System: 2. Data assimilation, J. Geophys. Res., 114, D13205, doi:10.1029/2008JD011115, 2009.

Bond, T. C., Doherty, S. J., Fahey, D. W., Forster, P. M., Berntsen, T. K., Boucher, O., DeAngelo, B. J., Flanner, M. G., Ghan, S. J., Kärcher, B., Koch, D. and Kinne, S., Kondo, Y., Lohmann, U., Quinn, P. K., Sarofim, M. C., Schultz, M., Schulz, M., Venkataraman, C., Zhang, H., Zhang, S., Bellouin, N., Guttikunda, S., Hopke, P. K., Jacobson, M. Z., Kaiser, J. W., Klimont, Z., Schwarz, J. P., Shindell, D., Storelvmo, T., Warren, S. G., and Zender, C. S.: Bounding the role of black carbon in the climate system: A scientific assessment, J. Geophys. Res., 118, 1-173, 2013.

Boucher, O., Pham, M., and Venkataraman, C.: Simulation of the atmospheric sulfur cycle in the LMD GCM: Model description, model evaluation, and global and European budgets, Note 23, 26 pp., Inst. Pierre-Simon Laplace, Paris, France, 2002.

Browell, E. V., Carter, A. F., Shipley, S. T., Allen, R. J., Butler, C. F., Mayo, M. N., Siviter, J. H., and Hall, W. M.: NASA Multipurpose Airborne DIAL System and Measurements of Ozone and Aerosol Profiles, Appl. Optics, 22, 522-534, 1983

Channan, S., Collins, K., and Emanuel, W. R.: Global mosaics of the standard MODIS land cover type data, University of Maryland and the Pacific Northwest National Laboratory, College Park, Maryland, USA, 2014.

Choi, J.-O. and Chung, C.-E.: Sensitivity of aerosol direct radiative forcing to aerosol vertical profile, Tellus B, 66, 24376, doi:10.3402/tellusb.v66.24376, 2014.

Colarco, P.: The NASA GEOS-5 Aerosol Forecasting System, in: MACC Conference, Driebergen, the Netherlands, 2011.

Dahlkötter, F., Gysel, M., Sauer, D., Minikin, A., Baumann, R., Seifert, P., Ansmann, A., Fromm, M., Voigt, C., and Weinzierl, B.: The Pagami Creek smoke plume after long-range transport to the upper troposphere over Europe - aerosol properties and black carbon mixing state, Atmos. Chem. Phys., 14, 6111-6137, doi:10.5194/acp-14-6111-2014, 2014.

Damenov, A. and da Silva, A.: The Quick Fire Emissions Dataset (QFED) - Documentation of versions 2.1, 2.2 and 2.4, NASA Technical Report Series on Global Modeling and Data Assimilations, Vol. 32, 1-183, 2013.

Dozier, J.: A method for satellite identification of surface temperature fields of subpixel resolution, Remote Sens. Environ., 11, 221-229, doi:10.1016/0034-4257(81)90021-3, 1981.

Flemming, J., Huijnen, V., Arteta, J., Bechtold, P., Beljaars, A., Blechschmidt, A.-M., Diamantakis, M., Engelen, R. J., Gaudel, A., Inness, A., Jones, L., Josse, B., Katragkou, E., Marecal, V., Peuch, V.-H., Richter, A., Schultz, M. G., Stein, O., and Tsikerdekis, A.: Tropospheric chemistry in the Integrated Forecasting System of ECMWF, Geosci. Model Dev., 8, 975-1003, doi:10.5194/gmd-8-975-2015, 2015.

Flentje, H.: Using Ceilometers for the evaluation of MACC-II Modelled Aerosol Profiles, MACC-II Deliverable D_85.4, 2014.

Freeborn, P. H., Wooster, M. J., Roberts, G., Malamud, B. D., and $\mathrm{Xu}, \mathrm{W} .:$ Development of a virtual active fire product for Africa through a synthesis of geostationary and polar orbiting satellite data, Remote Sens. Environ., 113, 1700-1711, 2009.

Freeborn, P. H. and Wooster, M. J.: Addressing the spatiotemporal sampling design of MODIS to provide estimates of the fire ra- 
diative energy emitted from Africa, Remote Sens. Environ., 115, 475-489, 2011.

Freitas, S. R., Longo, K. M., and Andreae, M. O.: Impact of including the plume rise of vegetation fires in numerical simulations of associated atmospheric pollutants, Geophys. Res. Lett., 33, L17808, doi:10.1029/2006g1026608, 2006.

Freitas, S. R., Longo, K. M., Chatfield, R., Latham, D., Silva Dias, M. A. F., Andreae, M. O., Prins, E., Santos, J. C., Gielow, R., and Carvalho Jr., J. A.: Including the sub-grid scale plume rise of vegetation fires in low resolution atmospheric transport models, Atmos. Chem. Phys., 7, 3385-3398, doi:10.5194/acp-7-3385-2007, 2007.

Freitas, S. R., Longo, K. M., Trentmann, J., and Latham, D.: Technical Note: Sensitivity of 1-D smoke plume rise models to the inclusion of environmental wind drag, Atmos. Chem. Phys., 10, 585-594, doi:10.5194/acp-10-585-2010, 2010.

Fromm, M., Bevilacqua, R., Servranckx, R., Rosen, J., Thayer, J. P., Herman, J., and Larko, D.: Pyro-cumulonimbus injection of smoke to the stratosphere: observations and impact of a super blowup in northwestern Canada on 3-4 August 1998, J. Geophys. Res.-Atmos., 110, D08205, doi:10.1029/2004JD005350, 2005.

Fromm, M., Lindsey, D. T., Servranckx, R., Yue, G., Trickl, T., Sica, R., Doucet, P., and Godin-Beekmann, S.: The untold story of Pyrocumulonimbus, B. Am. Meteorol. Soc., 91, 1193-1209, doi:10.1175/2010BAMS3004.1, 2010.

Giglio, L., Csiszar, I., and Justice, C. O.: Global distribution and seasonality of active fires as observed with the Terra and Aqua MODIS sensors, J. Geophys. Res.-Biogeo., 111, G02016, doi:10.1029/2005JG000142, 2006.

Giglio, L., Randerson, J. T., van der Werf, G. R., Kasibhatla, P. S., Collatz, G. J., Morton, D. C., and DeFries, R. S.: Assessing variability and long-term trends in burned area by merging multiple satellite fire products, Biogeosciences, 7, 1171-1186, doi:10.5194/bg-7-1171-2010, 2010.

Giglio, L., Randerson, J. T., and van der Werf, G. R.: Analysis of daily, monthly, and annual burned area using the fourthgeneration global fire emissions database (GFED4) J. Geophys. Res.-Biogeo., 118, 317-328, doi:10.1002/jgrg.20042, 2013.

Hair, J. W., Hostetler, C. A., Cook, A. L., Harper, D. B., Ferrare, R. A., Mack, T. L., Welch, W., Izquierdo, L. R., and Hovis, F. E.: Airborne high spectral resolution lidar for profiling aerosol optical properties, Appl. Optics, 47, 6734-6752, doi:10.1364/ao.47.006734, 2008.

Heald, C. L., Ridley, D. A., Kroll, J. H., Barrett, S. R. H., CadyPereira, K. E., Alvarado, M. J., and Holmes, C. D.: Contrasting the direct radiative effect and direct radiative forcing of aerosols, Atmos. Chem. Phys., 14, 5513-5527, doi:10.5194/acp-14-55132014, 2014.

Heil, A., Kaiser, J. W., van der Werf, G. R., Wooster, M. J., Schultz, M. G., and Dernier van der Gon, H.: Assessment of the RealTime Fire Emissions (GFASv0) by MACC, Tech. Memo. 628, ECMWF, Reading, UK, 2010.

Hollingsworth, A., Engelen, R. J., Textor, C., Benedetti, A., Boucher, O., Chevallier, F., Dethof, A., Elbern, H., Eskes, H., Flemming, J., Granier, C., Kaiser, J. W., Morcrette, J.-J., Rayner, P., Peuch, V.-H., Rouil, L., Schultz, M. G., and Simmons, A. J.: Toward a Monitoring and Forecasting System For Atmospheric Composition: The GEMS Project, B. Am. Meteorol. Soc., 89, 1147-1164, 2008.
Ichoku, C. and Kaufman, Y. J.: A method to derive smoke emission rates from MODIS fire radiative energy measurements, IEEE T. Geosci. Remote Sens., 43, 2636-2649, 2005.

Ichoku, C. and Ellison, L.: Global top-down smoke-aerosol emissions estimation using satellite fire radiative power measurements, Atmos. Chem. Phys., 14, 6643-6667, doi:10.5194/acp14-6643-2014, 2014.

Kahn, R. A., Li, W.-H., Moroney, C., Diner, D. J., Martonchik, J. V., and Fishbein, E.: Aerosol source plume physical characteristics from space-based multiangle imaging, J. Geophys. Res.-Atmos., 112, D11205, doi:10.1029/2006JD007647, 2007.

Kahn, R. A., Chen, Y., Nelson, D. L., Leung, F.-Y., Li, Q., Diner, D. J., and Logan, J. A.: Wildfire smoke injection heights: two perspectives from space, Geophys. Res. Lett., 35, L04809, doi:10.1029/2007GL032165, 2008.

Kaiser, J. W., Suttie, M., Flemming, J., Morcrette, J.-J., Boucher, O., and Schultz, M. G.: Global Real-time Fire Emission Estimates Based on Space-borne Fire Radiative Power Observations, AIP Conf. Proc., 1100, 645-648, 2009.

Kaiser, J. W., Heil, A., Andreae, M. O., Benedetti, A., Chubarova, N., Jones, L., Morcrette, J.-J., Razinger, M., Schultz, M. G., Suttie, M., and van der Werf, G. R.: Biomass burning emissions estimated with a global fire assimilation system based on observed fire radiative power, Biogeosciences, 9, 527-554, doi:10.5194/bg-9-527-2012, 2012.

Kessler, E.: On the distribution and continuity of water substance in atmospheric circulation models, Meteor. Monographs, Vol. 10, 1-84, Am. Meteorol. Soc. Boston, MA, 1969.

Kolusu, S. R., Marsham, J. H., Mulcahy, J., Johnson, B., Dunning, C., Bush, M., and Spracklen, D. V.: Impacts of Amazonia biomass burning aerosols assessed from short-range weather forecasts, Atmos. Chem. Phys., 15, 12251-12266, doi:10.5194/acp-15-12251-2015, 2015.

Kukkonen, J., Nikmo, J., Sofiev, M., Riikonen, K., Petäjä, T., Virkkula, A., Levula, J., Schobesberger, S., and Webber, D. M.: Applicability of an integrated plume rise model for the dispersion from wild-land fires, Geosci. Model Dev., 7, 2663-2681, doi:10.5194/gmd-7-2663-2014, 2014.

Latham, D.: PLUMP: A one-dimensional plume predictor and cloud model for fire and smoke managers, General Technical Report INT-GTR-314, Intermountain Research Station, USDA Forest Service, November 1994.

Marenco, F., Johnson, B., Langridge, J. M., Mulcahy, J., Benedetti, A., Remy, S., Jones, L., Szpek, K., Haywood, J., Longo, K., and Artaxo, P.: On the vertical distribution of smoke in the Amazonian atmosphere during the dry season, Atmos. Chem. Phys., 16, 2155-2174, doi:10.5194/acp-16-2155-2016, 2016.

Morcrette, J.-J., Boucher, O., Jones, L., Salmond, D., Bechtold, B., Beljaars, A., Benedetti, A., Bonet, A., Kaiser, J. W., Razinger, M., Schulz, M., Serrar, S., Simmons, A. J., Sofiev, M., Suttie, M., Tompkins, A. M., and Untch, A.: Aerosol analysis and forecast in the European Centre for Medium-Range Weather Forecasts Integrated Forecast System: Forward modeling, J. Geophys. Res. 114, D06206, doi:10.1029/2008JD011235, 2009.

Nelson, D., Garay, M., Kahn, R., and Dunst, B.: Stereoscopic Height and Wind Retrievals for Aerosol Plumes with the MISR INteractive eXplorer (MINX), Remote Sens., 5, 4593-4628, doi:10.3390/rs5094593, 2013. 
Palm, S. P., Benedetti, A., and Spinhirne, J.: Validation of ECMWF global forecast model parameters using GLAS atmospheric channel measurements, Geophys. Res. Lett., 32, L22S09, doi:10.1029/2005GL023535, 2005.

Paugam, R., Wooster, M., Atherton, J., Freitas, S. R., Schultz, M. G., and Kaiser, J. W.: Development and optimization of a wildfire plume rise model based on remote sensing data inputs - Part 2, Atmos. Chem. Phys. Discuss., 15, 9815-9895, doi:10.5194/acpd-15-9815-2015, 2015.

Paugam, R., Wooster, M., Freitas, S., and Val Martin, M.: A review of approaches to estimate wildfire plume injection height within large-scale atmospheric chemical transport models, Atmos. Chem. Phys., 16, 907-925, doi:10.5194/acp-16-907-2016, 2016.

Pergaud, J., Masson, V., Malardel, S., and Couvreux, F.: A parameterization of dry thermals and shallow cumuli for mesoscale numerical weather prediction, Bound.-Lay. Meteorol., 132, 83106, 2009.

Peterson, D. A., Hyer, E. J., Campbell, J. R., Fromm, M. D., Hair, J. W., Butler, C. F., and Fenn, M. A.: The 2013 Rim Fire: Implications for Predicting Extreme Fire Spread, Pyroconvection, and Smoke Emissions, B. Am. Meteorol. Soc., 96, 229-247, 2015.

Peuch, V.-H. and Engelen, R. J.: Towards and operational GMES Atmosphere Monitoring Service, ECMWF Newsletter No. 132, 20-25, 2012.

Reddy, M. S., Boucher, O., Bellouin, N., Schulz, M., Balkanski, Y., Dufresne, J.-L., and Pham, M.: Estimates of global multicomponent aerosol optical depth and direct radiative perturbation in the Laboratoire de Meteorologie Dynamique general circulation model, J. Geophys. Res., 110, D10S16, doi:10.1029/2004JD004757, 2005.

Reid, J. S., Hyer, E. J., Prins, E. M., Westphal, D. L., Zhang, J., Wang, J., Christopher, S. A., Curtis, C. A., Schmidt, C. C., Eleuterio, D. P., Richardson, K. A., and Hoffman, J. P.: Global Monitoring and Forecasting of Biomass-Burning Smoke: Description of and Lessons from the Fire Locating and Modeling of Burning Emissions (FLAMBE) Program, IEEE J. Selected Topics Appl. Earth Observations and Remote Sens., 2, 144-162, 2009.

Remy, S. and Kaiser, J. W.: Daily global fire radiative power fields estimation from one or two MODIS instruments, Atmos. Chem. Phys., 14, 13377-13390, doi:10.5194/acp-14-13377-2014, 2014.

Roberts, G., Wooster, M. J., and Lagoudakis, E.: Annual and diurnal african biomass burning temporal dynamics, Biogeosciences, 6 , 849-866, doi:10.5194/bg-6-849-2009, 2009.

Saide, P. E., Peterson, D. A., da Silva, A., Anderson, B., Ziemba, L. D., Diskin, G., Sachse, G., Hair, J., Butler, C., Fenn, M., Jimenez, J. L., Campuzano-Jost, P., Perring, A. E., Schwarz, J. P., Markovic, M. Z., Russell, P., Redemann, J., Shinozuka, Y., Streets, D. G., Yan, F., Dibb, J., Yokelson, R., Toon, O. B., Hyer, E., and Carmichael, G. R.: Revealing important nocturnal and day-to-day variations in fire smoke emissions through a multiplatform inversion, Geophys. Res. Lett., 42, 3609-3618, doi:10.1002/2015GL063737, 2015.

Schroeder, W., Ellicott, E., Ichoku, C., Ellison, L., Dickinson, M. B., Ottmar, R. D., Clements, C., Hall, D., Ambrosia, V., and Kremens, R.: Integrated active fire retrievals and biomass burning emissions using complementary near-coincident ground, airborne and spaceborne sensor data, Remote Sens. Environ., 140, 719-730, doi:10.1016/j.rse.2013.10.010, 2014.
Sofiev, M., Vankevich, R., Lotjonen, M., Prank, M., Petukhov, V., Ermakova, T., Koskinen, J., and Kukkonen, J.: An operational system for the assimilation of the satellite information on wildland fires for the needs of air quality modelling and forecasting, Atmos. Chem. Phys., 9, 6833-6847, doi:10.5194/acp-9-68332009, 2009.

Sofiev, M., Ermakova, T., and Vankevich, R.: Evaluation of the smoke-injection height from wild-land fires using remote-sensing data, Atmos. Chem. Phys., 12, 1995-2006, doi:10.5194/acp-12-1995-2012, 2012.

Sofiev, M., Vankevich, R., Ermakova, T., and Hakkarainen, J.: Global mapping of maximum emission heights and resulting vertical profiles of wildfire emissions, Atmos. Chem. Phys., 13, 7039-7052, doi:10.5194/acp-13-7039-2013, 2013.

Strada, S., Freitas, S. R., Mari, C., Longo, K. M., and Paugam, R.: One-dimensional simulation of fire injection heights in contrasted meteorological scenarios with PRM and MesoNH models, Geosci. Model Dev. Discuss., 6, 721-790, doi:10.5194/gmdd-6-721-2013, 2013.

Textor, C., Schulz, M., Guibert, S., Kinne, S., Balkanski, Y., Bauer, S., Berntsen, T., Berglen, T., Boucher, O., Chin, M., Dentener, F., Diehl, T., Easter, R., Feichter, H., Fillmore, D., Ghan, S., Ginoux, P., Gong, S., Grini, A., Hendricks, J., Horowitz, L., Huang, P., Isaksen, I., Iversen, I., Kloster, S., Koch, D., Kirkevåg, A., Kristjansson, J. E., Krol, M., Lauer, A., Lamarque, J. F., Liu, X., Montanaro, V., Myhre, G., Penner, J., Pitari, G., Reddy, S., Seland, $\varnothing .$, Stier, P., Takemura, T., and Tie, X.: Analysis and quantification of the diversities of aerosol life cycles within AeroCom, Atmos. Chem. Phys., 6, 1777-1813, doi:10.5194/acp-6-1777-2006, 2006.

Tosca, M. G., Randerson, J. T., Zender, C. S., Nelson, D. L., Diner, D. J., and Logan, J. A.: Dynamics of fire plumes and smoke clouds associated with peat and deforestation fires in Indonesia, J. Geophys. Res., 116, D08207, doi:10.1029/2010JD015148, 2011.

Troen, I. and Mahrt, L.: A simple model of the atmospheric boundary layer; sensitivity to surface evaporation, Bound.-Lay. Meteorol., 37, 129-148, 1986.

Twomey, S.: The influence of pollution on the shortwave albedo of clouds, J. Atmos. Sci., 34, 1149-1152, doi:10.1175/15200469(1977)034<1149:TIOPOT>2.0.CO;2, 1977.

Val Martin, M., Logan, J. A., Kahn, R. A., Leung, F.-Y., Nelson, D. L., and Diner, D. J.: Smoke injection heights from fires in North America: analysis of 5 years of satellite observations, Atmos. Chem. Phys., 10, 1491-1510, doi:10.5194/acp-10-14912010, 2010.

Val Martin, M., Kahn, R. A., Logan, J. A., Paugam, R., Wooster, M., and Ichoku, C.: Space-based observational constraints for 1D fire smoke plume-rise models, J. Geophys. Res., 117, D22204, doi:10.1029/2012JD018370, 2012.

van der Werf, G. R., Randerson, J. T., Giglio, L., Collatz, G. J., Mu, M., Kasibhatla, P. S., Morton, D. C., DeFries, R. S., Jin, Y., and van Leeuwen, T. T.: Global fire emissions and the contribution of deforestation, savanna, forest, agricultural, and peat fires (19972009), Atmos. Chem. Phys., 10, 11707-11735, doi:10.5194/acp10-11707-2010, 2010.

Veira, A., Kloster, S., Wilkenskjeld, S., and Remy, S.: Fire emission heights in the climate system - Part 1: Global plume height pat- 
terns simulated by ECHAM6-HAM2, Atmos. Chem. Phys., 15, 7155-7171, doi:10.5194/acp-15-7155-2015, 2015a.

Veira, A., Kloster, S., Schutgens, N. A. J., and Kaiser, J. W.: Fire emission heights in the climate system - Part 2: Impact on transport, black carbon concentrations and radiation, Atmos. Chem. Phys., 15, 7173-7193, doi:10.5194/acp-15-7173-2015, 2015 b.

Wiedinmyer, C., Akagi, S. K., Yokelson, R. J., Emmons, L. K., AlSaadi, J. A., Orlando, J. J., and Soja, A. J.: The Fire INventory from NCAR (FINN): a high resolution global model to estimate the emissions from open burning, Geosci. Model Dev., 4, 625641, doi:10.5194/gmd-4-625-2011, 2011.
Wooster, M. J., Roberts, G., Perry, G. L. W., and Kaufman, Y. J.: Retrieval of biomass combustion rates and totals from fire radiative power observations: FRP derivation and calibration relationships between biomass consumption and fire radiative energy release, J. Geophys. Res., 110, D24311, doi:10.1029/2005JD006318, 2005. 